\title{
Repurposing the Combination Drug of Favipiravir, Hydroxychloroquine and Oseltamivir as a Potential Inhibitor Against SARS-CoV-2: A Computational Study
}

\section{Pooja Yadav}

Jaypee Institute of Information Technology

PAPIA CHOWDHURY ( $\sim$ papia.chowdhury@jiit.ac.in )

Jaypee Institute of Information Technology https://orcid.org/0000-0001-9702-2553

\section{Research Article}

Keywords: SARS-CoV-2, COVID-19, 3CLpro, Favipiravir, Hydroxychloroquine, Oseltamivir, RMSD, RMSF.

Posted Date: June 21st, 2021

DOI: https://doi.org/10.21203/rs.3.rs-628277/v1

License: (c) (i) This work is licensed under a Creative Commons Attribution 4.0 International License. Read Full License 


\title{
Repurposing the Combination Drug of Favipiravir, Hydroxychloroquine and Oseltamivir as a Potential Inhibitor against SARS-CoV-2:A Computational Study
}

\author{
Pooja $^{1}$ and Papia Chowdhury ${ }^{1 *}$
}

\author{
Department of Physics and Materials Science \& Engineering, Jaypee Institute of \\ Information Technology, Noida 201309, Uttar Pradesh, India.
}

\begin{abstract}
The virus SARS-CoV-2 has created a situation of global emergency all over the world from the last few months. We are witnessing a helpless situation due to COVID-19 as no vaccine or drug is effective against the disease. In the present study, we have tested the repurposing efficacy of some currently used combination drugs against COVID-19. We have tried to understand the mechanism of action of some repurposed drugs:Favipiravir $(\mathrm{F})$, Hydroxychloroquine $(\mathrm{H})$ and Oseltamivir $(\mathrm{O})$. The ADME analysis have suggested strong inhibitory possibility of $\mathrm{F}, \mathrm{H}, \mathrm{O}$ combination towards receptor protein of $3 \mathrm{CL}^{\text {pro }}$ of SARS-CoV-2 virus. The strong binding affinity, number of hydrogen bond interaction between inhibitor, receptor and lower inhibition constant computed from molecular docking validated the better complexation possibility of $\mathrm{F}+\mathrm{H}+\mathrm{O}: 3 \mathrm{CL}^{\text {pro }}$ combination. Various thermodynamical output from Molecular dynamics (MD) simulations like potential energy $\left(E_{\mathrm{g}}\right)$, temperature $(\mathrm{T})$, density, pressure, SASA energy, interaction energies, Gibbs free energy ( $\left.\Delta \mathrm{G}_{\text {bind }}\right)$ etc., also favored the complexation between $\mathrm{F}+\mathrm{H}+\mathrm{O}$ and $\mathrm{CoV}-2$ protease. Our in-silico results have recommended the strong candidature of combination drugs Favipiravir, Hydroxychloroquine and Oseltamivir as a potential lead inhibitor for targeting SARS-CoV-2 infections.
\end{abstract}

Keywords: SARS-CoV-2, COVID-19, 3CL ${ }^{\text {pro }}$, Favipiravir, Hydroxychloroquine, Oseltamivir, RMSD, RMSF.

*Corresponding author, Fax: +91 1202400986

E-mail: papia.chowdhury@jiit.ac.in 


\section{Introduction}

In $21^{\text {st }}$ century, from the last few months the whole world is witnessing the pandemic due to the recent outbreak by the disease COVID-19 caused by novel coronavirus. It is believed that the virus was originated from the wet meat market of Wuhan city of China sometime in December in 2019 [1,2]. Corona viruses are not new to the mankind. From the last few centuries, mankind had perceived the presence of these viruses in the form of avian flu virus around 2003 [3], Severe Acute Respiratory Syndrome Coronavirus (SARS-CoV) around 2003 [4], Middle East Respiratory Syndrome Coronavirus (MERS-CoV) around 2012 [5]. The latest pandemic disease COVID-19 that has created a public health emergency in this series aroused due to novel coronavirus:SARS-CoV-2 [6]. The whole scientific fraternity in the world is working hard day and night to get a medicine/vaccine to fight against this deadly virus, but the reality is that till date we have no definite medication for COVID-19. As of today, the $13^{\text {th }}$ June, 2021 according to WHO data there are 175,306,598 confirmed patients of COVID-19 disease and 3,792,777 deaths worldwide have been reported [7]. Globally the 387,209 new cases and 10,158 deaths have been reported on $13^{\text {th }}$ June. Besides South East Asia, the trend of affected case and death rate are increasing in America, Europe and Eastern Mediterranean regions day by day. The community transmission and clusters of the diseased cases as well as the death toll due to COVID-19 expanding till now. CoV-2 can easily spread by contact transmission. The infection can easily be transmitted through respiratory droplets and also through surface contamination. Aerosol transmission may be considered as another way of transmission of the disease [8]. Till now research outputs, says that the virus can easily be transmitted by symptomatic asymptomatic and presymptomatic patients [9-11]. There is an urgent need of effective treatment method to limit the transmission of this disease as early as possible.

Coronavirus is spherical in shape having diameter between $80-160 \mathrm{~mm}$. The spherical envelope surface is covered with spike glycoproteins $(\mathrm{S})$, membrane proteins $(\mathrm{M})$ and envelope proteins $(\mathrm{E})$ $[12,13]$. The main envelope of virus contains a spiral nucleocapsid which is formed by genomic RNA and phosphorylated nucleocapsid (N) protein [14]. The main genome of $\mathrm{CoV}$ is comprised of a longest known genome among RNA viruses which is a single-stranded positive-strand RNA ranging from $26 \mathrm{~Kb}$ to $32 \mathrm{~Kb}$ in length. Coronaviruses can be divided into four categories: $\alpha, \beta, \gamma$, and $\delta$. $\alpha$ and $\beta$ coronaviruses only infect mammals [15], while $\gamma$ and $\delta$ mainly infect birds [16]. SARS-CoV-2 is a novel

$\beta$-coronavirus. The $S$ proteins of the virus initiate the attachment and entry to the host cells through the 
receptor binding domain (RBD) which is loosely attract and attach to the virus surface [17]. All corona viruses use some key receptors to enter the host human cells. For SARS-CoV-2, the key receptor is angiotensin converting enzyme 2 (ACE2) [18]. After entering the host cell, airway trypsin-like protease (HAT), cathepsins and transmembrane protease serine 2 (TMPRSS2) split the S proteins of the virus and establish the penetration changes. Recent medical reports suggested that for CoV-2, the single N501T mutation in spike proteins may definitely have enhanced the virus's binding affinity for ACE2 [19]. So, development of targeted spike glycoprotein therapeutics against SARS-CoV-2 will definitely be a suitable option to combat COVID-19. In this direction many vaccines, antiviral drugs, broad spectrum antibiotics, herbal medicines nebulization techniques have been in use to reduce the viral load for the affected patients [20-23].

Researchers around the world are working to develop around 170 types of vaccines to deal with corona viruses out of which around 31 vaccines are following various human trial phases [24,25]. Though according to the medical application protocol, vaccine typically requires years of research, testing and several phase wise human trials before reaching to the clinic, but due to our latest health emergency scientists are racing to provide an effective and efficient vaccine/drug for the mankind as soon as possible. According to today's world situation, none of the tested vaccine has shown satisfactory impact against COVID-19. So we are in an urgent need of an effective drug which will act as answer to this devastating virus. Drug development also is a time-consuming process which includes laboratory development, animal testing, and clinical trials in people before it reaches to market which can take a decade for a new drug to appear in market. So, to combat with current COVID emergency, researchers and medical practitioners are working on different available drugs that are already approved for other medical conditions, or have been tested on other viral diseases. The concept is known as drug repurposing which has become very important way now to identify potential drugs against the CoV-2 virus [26]. Among different options of repurposing drugs, mainly antiviral drugs which are already in use for other viral diseases like influenza, Ebola, HIV, hepatitis, Zika, Alzheimer's etc., are largely been used to treat the COVID-19 disease [27-30]. Usually any antiviral drug targets the infecting virus in three vital stages. The drug may resist the virus from entering the living cell, it can prevent the virus from replicating inside the human organ or it can minimize the damages that the infecting virus does to the human organs [31]. If the antiviral drug can resist the virus from entering the living cell before the virus has the chance to replicate itself, then only the significant damage/ failure of various body organs like lungs, kidney, heart, blood clotting can be avoided. A single antiviral drug can target multiple 
proteins. In current medical industry we have many examples of such type of antiviral drugs which have multiple use. Similarly, overlapped molecular pathways are also observed for many diseases. For example, Sofosbuvir, Ribavirin and Remdesivir are well known approved drugs for hepatitis $\mathrm{C}$ virus [32]. Remdesivir has also established its strong repurposing potential against Ebola, Zika viruses and now CoV-2 virus [33]. Remdesivir has shown very effective impact on CoV-2 infection by blocking the replication of the virus inside human body [34]. Favipiravir and Oseltamivir have been investigated for the treatment of Ebola virus, Lassa virus and influenza viruses A and B. Similarly, Lopinavir and Ritonavir were originally developed for the treatment of HIV patients. Now in current CoV-2 emergency situation all the above-mentioned viral medicines are being used to treat COVID-19 patients [35]. Like antiviral drugs, many available antibiotic drugs like Doxycycline, Chloroquine, Hydroxychloroquine etc., also are being used as repurposed drugs for the treatment of various bacterial and viral diseases. Normally antibiotic drugs attacked the walls of a bacteria. Also, these drugs prevent the bacteria from synthesizing a molecule in the cell wall called peptidoglycan. Peptidoglycan provides the wall with the strength it needs to survive in the human body [36]. Doxycyclineis frequently used for the treatment of various infections by gram-positive and gram-negative bacteria, aerobes and anaerobes and also for other types of bacteria [37]. For the treatment of malaria, rheumatoid arthritis, chronic discoid lupus erythematosus [38] Hydroxychloroquine is being actively used. For COVID-19 treatment some individual antiviral and antibiotic drugs have already shown lower to moderate effectiveness when tested against infections in patients. Some of them are:Chloroquine, Hydroxychloroquine, Nafamostat, Nitazoxanide, Remdesivir, Ribavirin, Penciclovir, Ritonavir, AAK1, Baricitinib, Choline and Arbidol [21, 35,39-41].

Another effective way of treatment which clinicians are using to fight against COVID-19 is combination drug therapy where two or more different known antiparasitic drugs, immunomodulators or natural remedies are used to treat COVID-19 patients. Combination drugs have already proved their effectiveness to combat against HIV and other coronaviruses earlier [20, 42,43]. Combination drugs have shown their efficiency for the treatment of MERS-CoV infection [44]. Lopinavir and Ritonavir combination is one of the mostly tested repurposed combination medicine for the treatment of MERSCoV infection [45]. Another combination of drug of Mycophenolic acid (MPA) and IFN- $®$ has proved its strong effectiveness against MERS-CoV affected diseases [46]. In most of the above-mentioned cases, application of combination drugs has been proved to be success as most of the patients were declared clinically recovered [47]. However, to data a very low success rate of combination drugs 
against CoV-2 virus is available which may be due to the fact that majority of COVID-19 clinical trials are evaluating repurposed drugs as monotherapy [48]. With the lack of effective treatment against CoV2 infections WHO has identified some therapies which doctors and medical researchers believe as most promising for COVID-19 treatment as combination of two or more repurposing drugs like HIV drugs (lopinavir and ritonavir), anti-malarial drugs (chloroquine and hydroxychloroquine) [49].

For COVID-19 treatment antibiotic and antiviral drug combination of Hydroxychloroquine and Favipiravir is already being tested [35]. Similarly, the combination of Hydroxychloroquine + Azithromycin [50], Favipiravir+ Nafamostat mesylate [51] or Lopinavir+ Oseltamivir + Ritonavir [35] are already in use against SARS-CoV-2 infection. Among the first trials published of effective treatment for COVID-19 was a triple combination of interferon beta-1b, lopinavir-ritonavir and ribavirin for COVID-19 hospitalized patients [52]. In comparison to mono/ dual therapy, the triple combination drug therapy showed faster viral clearance and alleviation of symptoms, and shorter hospital stays. Till now it is unclear that whether mono or combination therapy suggest better clinical benefits for hospitalized COVID-19 patients. Despite detailed available information about all repurposed drugs there has been limited research activities available with combination therapy for COVID-19. As per latest data, among 1971 registered clinical trials only 258 trials are evaluating combination therapies against CoV-2. Out of these 120 trials are taking step wise approach and 138 are evaluating combination strategies [53]. However due to the lack of positive result, the search for various other combination drugs cannot pause because the demand for new effective agents is huge. Still there is no solid evidence of $100 \%$ effectiveness of any combination drug against COVID-19 till now. So, we have taken a challenge to test the applicability of repurposing of already used individual drugs for COVID-19 treatment. In the present study, we have tried to understand the mechanism of action of some mostly applicable repurposed antiviral and antibiotic drugs individually and in their combination applicability for COVID-19 treatment. Our proposed drugs are Favipiravir,Hydroxychloroquineand Oseltamivirand their proposed combination as Favipiravir +Hydroxychloroquine +Oseltamivir. Like all positive RNA viruses for CoV2, RdRp (nsp12 protein) lies at the core of viral replication machinery. Due to its viral life cycle, lack of host homologous, high level of sequence and structural conservation nsp12 becomes an optimal target for therapeutics. But till now due to the lack of sufficient fundamental data, proper guide to design of an efficient antiviral therapeutics and their mechanism of action is not available. So RdRp inhibitors are chosen a promising target drugs since they are small sized nucleoside analogues (NAs). RdRP is one of the most intriguing and promising drug targets for SARS-CoV-2 drug development. Favipiravir is one of 
such most effective RdRP inhibitor[54]. Favipiravir (T-705) is a synthetic prodrug, discovered during assessing the antiviral activity of chemical agents active against the influenza virus. Favipiravir comes to its active form favipiravir-RTP after it undergoes phosphoribosylation. In active form only it undergoes it antiviral effect. It is a target specific drug which acts as a substrate for RNA-dependent RNApolymerase (RdRp) enzyme, which is mistaken by the viral enzyme as a purine nucleotide and so the viral protein allows it to inhibit by forming viral protein-RdRp complex form exonuclease (ExoN) [55]. During inhibition into the viral RdRp enzyme, facile insertion of favipiravir into viral RNA happens sparing human DNA. After inhibition it leads to termination of the viral protein synthesis as it gets incorporated in the viral RNA strand preventing protein's further extension. It is reported that SARS CoV-2-RdRp complex is at least 10-fold more active than any other reported viral RdRp known. For CoVs the exonuclease has been shown to remove certain NAs after insertion by RdRp into nascent RNA which reduces their antiviral effects. Despite this, several NAs like Favipiravir are currently being tested as anti $\mathrm{CoV}$ candidates. It is also reported that favipiravir can induces mutagenesis in vitro during influenza virus infection as it can inactivate the virus either by killing them or by changing their surface structure so the virus can't be able to enter the host cells. There are many reported clinical studies on its activities for other corona viruses like SARS-CoV and MERS-CoV, as well as other RNA virus infections[56]. Though the proper interaction is still unknown, we are expecting similar activity of favipiravir against SARS CoV-2 protein. We hope that Favipiravir with its defined mode of action may well find a place as an anti RdRp component in combination therapies targeting corona viruses. Our tested antiviral drugs Favipiravir and Oseltamivir have shorten the course of the disease by targeting the key enzymes of SARS-CoV-2, thus interfering with the viral cycle inside the host cell, reducing the viral load and viral shedding. From the clinical studies in COVID-19, Favipiravir has shown speedy viral clearance as compared to lopinavir/ritonavir and greater recovery rate than umifenovir[56]. In targeting the viral RdRP, favipiravir could be promising in combination with other antiviral/antibiotic agents for treatment of COVID-19. Hydroxychloroquine is used in the treatment of malaria, systemic lupus erythematosus [57]. The bioavailability of hydroxychloroquine is 67-74\%. According to available data the Hydroxychloroquine rises the $\mathrm{pH}$ value in human organelles [58]. The raised $\mathrm{pH}$ in human organelles can prevent virus particles (such as SARS-CoV and SARS-CoV-2) from utilizing their activity for fusion and entry into the cell. Oseltamivir is an antiviral drug, which is used for the treatment and prophylaxis of infection with influenza viruses A and B [59]. Oseltamivir exerts its antiviral activity by inhibiting the activity of the viral neuraminidase enzyme found on the surface of the virus, which 
prevents budding from the host cell, viral replication, and infectivity [35]. Mostly antiviral agents and some antibiotics have been used against SARS-CoV-2 clinically, though the clinical data is still limited. Clinical trials for COVID-19 treatment are currently underway which combines Favipiravir with Hydroxychloroquine and Oseltamivir. It is the goal of our present study that guanine analogs such as Favipiravir can be proved to be effective in double-blind clinical trials against SARS-CoV-2 so that clinicians may have another tool to treat patients in the emergency room. To understand the interaction between receptor $3 \mathrm{CL}^{\text {pro }}$ protease and inhibitor ligand drugs we have applied some simulation techniques like energy minimization, molecular docking and molecular dynamics (MD) simulations.

\section{Materials and Methods:}

\subsection{Procedure of potential target protein structures for SARS-CoV-2}

The structure of CoV-2 virus has been characterized very rapidly after its appearance to the world [60]. The structures of newly invented CoV-2 virus and already known CoV virus is very similar [61]. The similarity index is about $95 \%$. So the identification process of 3-chymotrypsinlike viral protease $\left(3 \mathrm{CL}^{\mathrm{pro}}\right)$ of $\mathrm{CoV}-2$ was appeared to be much faster [62,63]. After the appearance of $\mathrm{CoV}-2$ virus, till now there are more than 160 reported compounds (co-crystallized with SARS-CoV-2 Pro / CL pro) proteins have been identified. $\mathrm{CL}^{\text {pro }} / \mathrm{M}^{\text {pro }}$ forms an attractive pharmacological target for antiviral drug discovery. Inhibitors of the SARS-CoV (2003) $\mathrm{M}^{\text {pro }}$ can act through a two-step irreversible inactivation mechanism. The inhibitor first associates with the $\mathrm{M}^{\text {pro }}$ to form enzyme-inhibitor complex with an equilibrium binding constant. Then, a stable covalent bond is formed between the inhibitors and $\mathrm{M}^{\mathrm{pro}}[64,65]$. There are many SARS-CoV-2 $\mathrm{M}^{\text {pro }} / \mathrm{CL}^{\text {pro }}$ reported like 5r7y, 5r7z, 5r80, 5r81, 5r82, 5r83, 5r84, 6lu7 and 6y7m, 5RFS proteins are being used with various inhibitor like alkaloids, terpenoid, phenolic compounds[66,67]. Among them, 6LU7 is used as main protease in CoV enzyme, which plays a crucial role in mediating viral replication and transcription, making it an better drug target for this virus. In the present study, we have used 6LU7, a 3CL pro proteasesas main target protein of drug molecules. Another reason for choosing the said protein is that the crystal structure of $\mathrm{M}^{\text {pro }}$ protein (6LU7) is now totally known to us in its compound form. The known protein structure information always helps to demonstrate the efficacy of the drug screening strategy which leads to rapid discovery of drugs. The 3D structure of the $6 \mathrm{LU} 7$ of CoV-2 was retrieved from the Protein Data Bank website (https://www.rcsb.org) [68] shown in table 1 and used as a receptor. First of all, from the protein structure the existing water molecules were removed. After that polar hydrogens were added in protein 
structure. After that, with the help of Discovery studio 2020 the inbuilt ligand was removed from the protein structure [69]. All of the above steps were performed in AutoDock [70], MGL tools [71]. The output protein structure was saved in PDB format.

\subsection{Procedure of Ligand drug molecules preparations}

For the screening of F, H and O drugs the SWISS ADME software (https://www.swissadme.ch) and ADMET (https://vnnadmet.bhsai.org/) [72] software were used. Before doing the screening the inhibition capability were checked of above mentioned drugs. For screening of different available drugs there are some Drug-likeness rules like Lipinski's rule of five (Ro5), Veber's rule, MDDR-like rule, Egan rule, Ghose filter, Muegge rule etc., which are used for preliminary drug screening [73-75].

Table 1: Structure of receptor protein (6LU7), Favipiravir (F), Hydroxychloroquine (H) and Oseltamivir (O).

\begin{tabular}{|l|l|}
\hline Compound Name & Structure \\
\hline Protease:6LU7 & \\
\hline $\begin{array}{l}\text { Favipiravir }(\mathrm{F}) \\
\left(\mathrm{C}_{5} \mathrm{H}_{4} \mathrm{FN}_{3} \mathrm{O}_{2}\right)\end{array}$ & \\
\hline
\end{tabular}




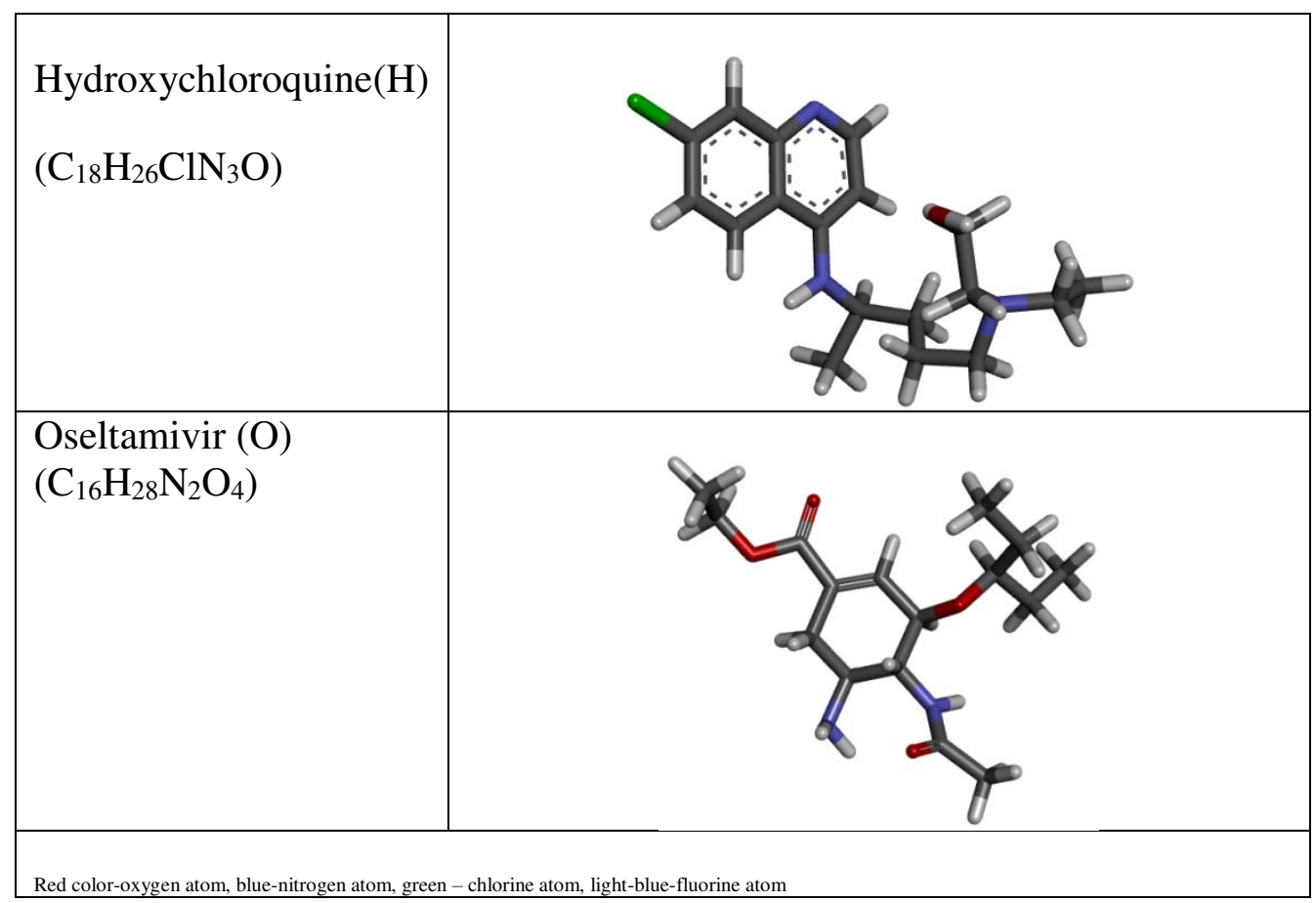

Among all of them Ro5 is the most important rule and also known as "a rule of thumb". The filters of Ro5 are followed by:Molecular weight less than equals to 500, $\mathrm{H}$-bond donors less than equals to 5, $\mathrm{H}$ bond acceptor less than equals to 10, MLOGP less than equals to 4.15 and molar refractivity between 30 and 140. Those drugs which follows the Ro5 with some required pharmacological properties can be used as a potential candidate for vocally active drug in humans [73]. For Drug preparation, the ligands in 'SDF' format were obtained directly from the PubChem (National Library of Medicine) (https://pubchem.ncbi.nlm.nih.gov/) and converted to 'PDB' format with the help of Autodock tools [70]. The ligand structures obtained from PubChem were not optimized structures. All ligands should be used at their optimized structures for any simulation. So energy minimization was the first step for the whole simulation process. So all molecular structures of the ligands were optimized by using density functional theory (DFT) with the basis set 6.311G (d,p) [76] using the Gaussian 09 program [77]. The optimized structures were visualized with the help of Gauss View 5 molecular visualization program [78].

\subsection{Molecular docking and visualization}

To examine the protein-ligand interaction we have used molecular docking mechanism using AutodockVina [70]. MGL tools of Autodock 4.2 was used for the preparation of protein and ligands for 
molecular docking. By using Autodock Vina and Discovery studio visualizer [69], the docking based studies and analysis of the recommended inhibitors against protease of SARS-CoV-2 have been performed. Firstly, with the help of Autodock4.2 the structures of prepared protein and ligand were saved in the format of Pdbqt [70]. A specific configuration file was used for AutodockVina algorithm. The parameters for configuration file were as follows: total no. of binding modes was taken as 9, exhaustiveness of the global search which is roughly proportional with timewas considered as 8 and maximum energy difference between best binding mode and worst binding mode was considered as 3 $\mathrm{Kcal} / \mathrm{mol}$. Grid box was formed with centers of $\mathrm{x}, \mathrm{y}, \mathrm{z}$ coordinate of residue position of the receptor protein respectively. The value of the centers of $\mathrm{x}, \mathrm{y}$ and $\mathrm{z}$ coordinates were considered as -10.729204 $\AA, 12.417653 \AA$ and $68.816122 \AA$ with their sizes as $30 \AA$ each in the grid box having a radius of the sphere as $13.709159 \AA[65,79,80]$. For docking based studies, these parameters were used for the recommended inhibitor on the protease of SARS-CoV-2 [81]. After the docking, there were nine different poses (ligand:proteincomplex structure) obtained. Among all of the poses, the best pose was chosen as such in which, shows maximum non bonded interaction, minimum binding affinity (Kcal/mol), dreiding energy, dipole moment and also minimum inhibition constant. To calculate inhibition constant, the equation used was

$$
K_{i}=e^{\Delta G / R T}
$$

Where, binding affinity is $\mathrm{G}$, universal constant is $\mathrm{R}$ and $\mathrm{T}$ temperature $(300 \mathrm{~K})$. Lowest value of inhibition constant $\left(\mathrm{k}_{i}\right)$ validate the strong interaction of ligands $(\mathrm{F}, \mathrm{H}, \mathrm{O})$ as inhibitor towards the receptor protein 6LU7. Again, for selecting best pose the maximum no. of hydrogen bond between ligand and receptor protein is another criteria. In this case, firstly, individual of three ligands were docked with receptor protein. After the analysis of individual docking the sequential docking were performed. For sequential docking, the grid box coordinates were established to the specific binding region of individually drug with default grid spacing. The interaction between receptor protein and ligand were analyzed with the help of Discovery Studio Visualizer [69]. After that the MD simulation is used for the already docked structure [82].

\subsection{Molecular Dynamic (MD) Simulations and MMPBSA Method}

To obtain the data at atomistic level MD simulation is used. It can simulate the data in picosecond (ps)/nanosecond(ns) and so it is the best verified silico method among the researchers [83, 84]. From MD simulation results, we can find out the structural dynamics of protein:ligand interaction at an 
atomistic level. In MD simulation for calculating thermodynamics parameters of the ligand:proteincomplex structure the LINUX based platform "GROMACS 5.1 Package " [82] with GROMOS43A2 force field [85] was used. For topology creation, we have used “ PRODRG” server. PRODRG works with the concept of charge groups, which are defined as a group of bonded atoms with an integer charge. To assign atomic charges it recognizes the charge groups first. After topology creation of protein and ligand, according to the procedure followed for MD simulation, TIP3P water model has been used and $4 \mathrm{Na}^{+}$ions were added to maintain the neutrality of individual protein and ligand:protein complex structures. Before MD simulation, energy minimization of the protein:ligand complex is the first step. All the structures should optimize means every structure has minimum potential energy $\left(E_{\mathrm{pot}}\right)$ and also negative maximum force value. For energy minimization of complex, time varying (1ps-100ps) steepest descent algorithm with for 500,00 steps was used. The algorithm has a cut off up to 239.006 $\mathrm{Kcal} / \mathrm{mol}$ for minimizing the steric clashes [86]. There are two phases to obtain the energy minimization of complex with each having 500,000 steps. In the first phase, minimization was obtained through a binary condition from constant particles no. (N), volume (V) and temperature (T) and in second phase particle number, pressure and temperature (NPT) under $\mathrm{P}=1 \mathrm{~atm}, \mathrm{~T}=300 \mathrm{~K}$. After the implementation of NVT and NPT conditions the each complex system becomes completely stable under equilibrium conditions. Throughout the MD simulation process many thermodynamic parameters for the complex system were computed. These thermodynamic parameters of the complex system are used to know the stability and to observe possible configuration changes of receptor protein in its bare state and complex structure at time resolved simulation trajectory. Some important thermodynamic parameters are RMSD, RMSF, potential energy, $\mathrm{R}_{\mathrm{g}}$, inter-molecular H-bonds, SASA various non-bonded interaction energies for protein:ligandcomplex structures. In MD simulation, to calculate intermolecular and intramolecular forces of the molecules the force field is the very important factor. From this we can estimate the potential energy for atoms and molecules in the complex.For the forcefield GROMOS43A2 various interaction energies have been computed. The different terms of energies are expressed in additive forms as:

$$
\begin{aligned}
& E_{\text {total }}=E_{\text {bonded }}+E_{\text {non bonded }} \ldots \ldots \ldots \ldots \ldots \ldots \ldots \ldots \ldots \ldots \text { (2) } \\
& E_{\text {bonded }}=E_{\text {bond }}+E_{\text {angle }}+E_{\text {dihedral }} \ldots \ldots \ldots \ldots \ldots \ldots \ldots \text { (3) } \\
& E_{\text {non bonded }}=E_{\text {hydrogen bond }}+E_{\text {electrostatic }}+E_{\text {vander waals }} \ldots \ldots \text { (4) } \\
& E_{\text {electrostatic }}=E_{\text {coulombic }}+E_{\text {lenard Jones }} \ldots \ldots \ldots \ldots \ldots \ldots \ldots \text { (5) }
\end{aligned}
$$


The thermodynamic parameters computed were : $\mathrm{E}_{\mathrm{pot}}, \mathrm{T}, \mathrm{D}, \mathrm{R}_{\mathrm{g}}, \mathrm{RMSD}, \mathrm{RMSF}, \mathrm{SASA}, \mathrm{H}-$ bonds and interaction energies. Short range Coulomb interaction (Coul-SR) and short range Lennard-Jones interaction (SR-LJ) are used for nonbonded interaction between protein and ligand. For binding energy computation for the complex structure, the data was collected at every 100ps between 0ps and 10000ps (10 ns) and between 0ps to 100000ps (100ns). Each MD simulation result has been verified by repeated simulation run (twice). When all the steps of MD simulation completed, after that the results were analyzed with the help of graphical tool origin. In this study, we have carried out MD simulations for the independent ligands $(\mathrm{F}, \mathrm{H}, \mathrm{O})$ and also for the combination modes $(\mathrm{F}+\mathrm{H}, \mathrm{F}+\mathrm{H}+\mathrm{O})$ in presence of target protein and studied the possibility of formation of complex structures in solvation modes.

To find the presence stronger ligand binding affinities towards receptor protein we have applied the MM/PBSA method. With the help of different quantum simulation techniques, there are a number of research works are going on to check the stability of varieties of complex configurations based on interaction energies $[87,88]$. For MM/PBSA method the Van der Waal energy $\left(E_{\mathrm{vdw}}\right)$ components and electrostatic energy (Eelectrostatic) components between inhibitor and receptor are used to determine the stability/binding affinity for all complex structures. The $\Delta \mathrm{E}_{\mathrm{MM}}$ was calculated by using molecular mechanics force field, polar part of the solvation free energy with linearized Poisson-Boltzmann model and apolar part using surface area approach. The solute and solvent dielectric constant and salt ionic strength used were 2.0 M 80.0 M and $0.15 \mathrm{M}$, respectively. Usually binding energy is calculated to identify the affinity of receptor protein towards a specific inhibitor. To calculate the interaction free energies for the protein:ligand complex structure $\left(\Delta \mathrm{G}_{\text {bind }}\right)$, the MMPBSA (Molecular Mechanics Poisson-Boltzmann Surface Area) method [89] sourced from the APBS and GROMACS packages have been used. This model has both repulsive and attractive components [90]. To calculate the binding energy the data was collected at every 100ps between 0ps and 10000ps (10 ns) and between 0ps to 100000 ps (100ns). In aqueous environment, the binding free energy of the ligand:receptor complex can be shown by following equations.

$$
\begin{array}{r}
\Delta G_{\text {bind,aqu }}=\Delta H-T \Delta S \approx \Delta E_{M M}+\Delta G_{\text {bind,solv }}-T \Delta S \ldots \ldots \ldots \ldots \ldots \\
\Delta E_{M M}=\Delta E_{\text {covalent }}+\Delta E_{\text {electrostatic }}+\Delta E_{\text {vander waals } \ldots .(7)} \\
\Delta E_{\text {covalent }}=\Delta E_{\text {bond }}+\Delta E_{\text {angle }}+\Delta E_{\text {torsion }} \ldots \ldots \ldots \ldots \ldots \ldots(8) \\
\Delta G_{\text {bind,solv }}=\Delta G_{\text {polar }}+\Delta G_{\text {nonpolar } \ldots \ldots \ldots \ldots \ldots \ldots \ldots \ldots} \ldots \ldots \ldots \ldots \ldots \ldots \ldots \ldots
\end{array}
$$


where, $-\mathrm{T} \Delta \mathrm{S}, \Delta G_{b i n d, s o l v}$ and $\Delta E_{M M}$, are the molecular conformational energy due to binding and solvation free energy and mechanical energy changes in gas phase, respectively.

\subsection{Computational details}

MD simulations and corresponding energy calculations have been computed in a single system using HP Intel Core i5 - 1035G1 CPU and 8 GB of RAM with Intel UHD Graphics and a 512 GB SSD.

\section{Results and discussion}

\subsection{Screening and Analysis of Drug Likeness properties of Favipiravir, Hydroxychloroquine and Oseltamivir}

For screening of different available drugs, there are some Drug-likeness rules which have already discussed in the section 2.2. F, H and O follow the Lipinski's rule of five (Ro5) (Table 2). All drugs have synthetic accessibility count $<5$, means all the drugs can synthesized easily. Also, they follow veber rule and so they all satisfy bioavailability conditions[73]. We have calculated various Physiochemical Properties, Fraction $\mathrm{CSp}^{3}$, Lipophilicity, Water Solubility, Pharmacokinetics and Medicinal Chemistry for the F, H and $\mathrm{O}$ dugs. Formal charge is the charge assigned to an atom in a molecule, assuming that electrons in all chemical bonds are shared equally between atoms, regardless of relative electronegativity. Also, from the ADMET analysis we can conclude that none of our tested drug has any cyto-toxicity effect. According to data calculated from ADMET software (https://vnnadmet.bhsai.org/), the maximum suggested dose for F, $\mathrm{H}$ and $\mathrm{O}$ were obtained as 170mg/day, $478 \mathrm{mg} /$ day and $165 \mathrm{mg} /$ day.

Table 2: Physiochemical, Drug-likeness, lipophilicity, water solubility and pharmacokinetics properties, Medicinal chemistry and toxicity of Favipiravir, Hydroxychloroquine and Oseltamivir.

\begin{tabular}{|l|l|l|l|}
\hline Name of Ligand & Favipiravir & Hydroxychloroquine & Oseltamivir \\
\hline \multicolumn{3}{|c|}{ Physiochemical Properties } \\
\hline Molecular Formula & $\mathrm{C}_{5} \mathrm{H}_{4} \mathrm{FN}_{3} \mathrm{O}_{2}$ & $\mathrm{C}_{18} \mathrm{H}_{26} \mathrm{C}_{1} \mathrm{~N}_{3} \mathrm{O}$ & $\mathrm{C}_{16} \mathrm{H}_{28} \mathrm{~N}_{2} \mathrm{O}_{4}$ \\
\hline Molecular Weight & $157.10 \mathrm{~g} / \mathrm{mol}$ & $335.87 \mathrm{~g} / \mathrm{mol}$ & $312.40 \mathrm{~g} / \mathrm{mol}$ \\
\hline $\begin{array}{l}\text { Hydrogen Bond Donor } \\
\text { Count }\end{array}$ & 2 & 2 & 2 \\
\hline $\begin{array}{l}\text { Hydrogen Bond } \\
\text { Acceptor Count }\end{array}$ & 4 & 3 & 5 \\
\hline Rotatable Bond Count & 1 & 9 & 9 \\
\hline $\begin{array}{l}\text { Topological Polar } \\
\text { Surface Area }\end{array}$ & $88.84 \AA^{2}$ & $48.39 \AA^{2}$ & $90.65 \AA^{2}$ \\
\hline
\end{tabular}




\begin{tabular}{|c|c|c|c|}
\hline Heavy Atom Count & 11 & 23 & 22 \\
\hline Fraction CSP $^{3}$ & 0 & 0.50 & 0.70 \\
\hline Formal Charge & 0 & 0 & 0 \\
\hline Molar Refractivity & 32.91 & 98.57 & 84.52 \\
\hline \multicolumn{4}{|c|}{ Lipophilicity } \\
\hline $\log P_{o / w}($ iLOGP) & 0.39 & 3.58 & 2.79 \\
\hline $\log P_{\mathrm{o} / \mathrm{w}}($ XLOGP3) & -0.56 & 3.58 & 1.10 \\
\hline $\log P_{\mathrm{o} / \mathrm{w}}($ WLOGP $)$ & -0.57 & 3.59 & 1.29 \\
\hline $\log P_{\mathrm{o} / \mathrm{w}}(\mathrm{MLOGP})$ & -1.30 & 2.35 & 0.63 \\
\hline$\overline{\log } P_{\mathrm{o} / \mathrm{w}}($ SILICOS-IT) & 0.69 & 3.73 & 1.33 \\
\hline Consensus $\log P_{\mathrm{o} / \mathrm{w}}$ & -0.27 & 3.37 & 1.43 \\
\hline \multicolumn{4}{|c|}{ Water Solubility } \\
\hline $\log S$ (SILICOS-IT) & -1.42 & -6.35 & -2.47 \\
\hline class & Soluble & Poorly soluble & soluble \\
\hline Solubility & $\begin{array}{l}6.04 \mathrm{e}+00 \\
\mathrm{mg} / \mathrm{ml} ; 3.85 \mathrm{e}- \\
02 \mathrm{~mol} / \mathrm{l}\end{array}$ & $\begin{array}{l}1.50 \mathrm{e}-04 \mathrm{mg} / \mathrm{ml} ; \\
4.46 \mathrm{e}-07 \mathrm{~mol} / \mathrm{l}\end{array}$ & $\begin{array}{l}1.05 \mathrm{e}+00 \mathrm{mg} / \mathrm{ml} ; \\
3.37 \mathrm{e}-03 \mathrm{~mol} / \mathrm{l}\end{array}$ \\
\hline \multicolumn{4}{|c|}{ Pharmacokinetics } \\
\hline $\begin{array}{l}\text { Gatrointestinal } \\
\text { absorption }\end{array}$ & High & High & High \\
\hline BBB permeant & No & Yes & No \\
\hline P-gp substrate & No & No & Yes \\
\hline CYP1A2 inhibitor & No & Yes & No \\
\hline CP2C19 inhibitor & No & No & No \\
\hline $\begin{array}{l}\text { Log } K_{\mathrm{p}} \text { (skin } \\
\text { permeation) }\end{array}$ & $-7.66 \mathrm{~cm} / \mathrm{s}$ & $-5.81 \mathrm{~cm} / \mathrm{s}$ & $-7.42 \mathrm{~cm} / \mathrm{s}$ \\
\hline \multicolumn{4}{|l|}{ Drug Likeness } \\
\hline Lipinski Rule & Yes; 0 violation & Yes; 0 violation & Yes; 0 violation \\
\hline Ghose Filter & $\begin{array}{l}\text { No; } 4 \\
\text { violations:MW } \\
<160, \\
\text { WLOGP<-0.4, } \\
\text { MR<40, } \\
\text { \#atoms<20 }\end{array}$ & Yes & Yes \\
\hline Veber (GSK) Rule & Yes & Yes & Yes \\
\hline $\begin{array}{l}\text { Egan (phatmacial) } \\
\text { Filter }\end{array}$ & Yes & Yes & Yes \\
\hline Muegge (Bayer) Filter & $\begin{array}{l}\text { No; } 1 \\
\text { violation:MW< } \\
200\end{array}$ & Yes & Yes \\
\hline $\begin{array}{l}\text { Bioavailability } \\
\text { (Abbott) Score }\end{array}$ & 0.55 & 0.55 & 0.55 \\
\hline \multicolumn{4}{|c|}{ Medicinal Chemistry } \\
\hline $\begin{array}{l}\text { PAINS (Pan Assey } \\
\text { Interference } \\
\text { Structures) } \\
\end{array}$ & 0 alert & 0 alert & 0 alert \\
\hline Brenk & 0 alert & 0 alert & 1 alert:phosphor \\
\hline
\end{tabular}




\begin{tabular}{|l|l|l|l|}
\hline Leadlikeness & $\begin{array}{l}\text { No; 1 } \\
\text { violation:MW }< \\
250\end{array}$ & $\begin{array}{l}\text { No; 2 } \\
\text { violations:Rotors }>7, \\
\text { XLOGP3>3.5 }\end{array}$ & $\begin{array}{l}\text { No; 1 } \\
\text { violation:Rotors >7 }\end{array}$ \\
\hline Synthetic accessibility & 2.08 & 2.82 & 4.449 \\
\hline \multicolumn{3}{|c|}{ Toxicity } \\
\hline Cyto-toxicity & No & No & No \\
\hline MRTD(mg/day) & 170 & 478 & 165 \\
\hline
\end{tabular}

\subsection{Analysis of molecular docking results}

In case of F, we have obtained 9 different pose structures depending on the variable binding affinity ($4.9--4.0 \mathrm{kcal} / \mathrm{mol}$ ). Pose 3 was considered as the best fit ligand:receptor (F:6LU7) complex structure (Figure 1a, Table 3). For pose 3 we obtained the best protein: ligand complex structure having binding energy $(-4.4 \mathrm{kcal} / \mathrm{mol})$, dreiding energy (53.0) and inhibition constant $\left(5.9 \times 10^{-4} \mathrm{M}\right)$ at $300 \mathrm{~K}$ (room temperature) depending upon the maximum number of intermolecular hydrogen bonding between protein and ligand. Similarly, in case of $\mathrm{H}$ and $\mathrm{O}$, for pose 1 we obtained the maximum intermolecular hydrogen bonding between protein and ligand. Also we obtained the binding energies $(-4.8 \mathrm{Kcal} / \mathrm{mol}$ and $-5.1 \mathrm{Kcal} / \mathrm{mol})$, dreiding energies (332.8 and 327.4) and inhibition constants $\left(3.0 \times 10^{-4} \mathrm{M}, 1.8 \times 10^{-}\right.$ ${ }^{4} \mathrm{M}$ ) at $300 \mathrm{~K}$ (room temperature) for best fit ligand:receptorcomplex structures for H:6LU7 and O:6LU7

(Figure 1b, c and SD1). Based on their crystal structure it was identified that CoV enzyme 6LU7 have some binding pockets within its protease which act as active sites. They are S1, S2, S3, S4. The active sites are comprises of side chain residues and backbone of the base protein. When individual ligand $\mathrm{F}$, H, O were interacting with 6LU7, F usually gets attached with THR24, THR25, CYS22, VAL42, CYS44, ILE 43 chain residues known as S2, H gets attached with GLU166, MET165, ARG188, THR190 chain residues as S4 and O gets attached with SER144, GLN189, LEU141, CYS145 chain residues as S1binding sites. 

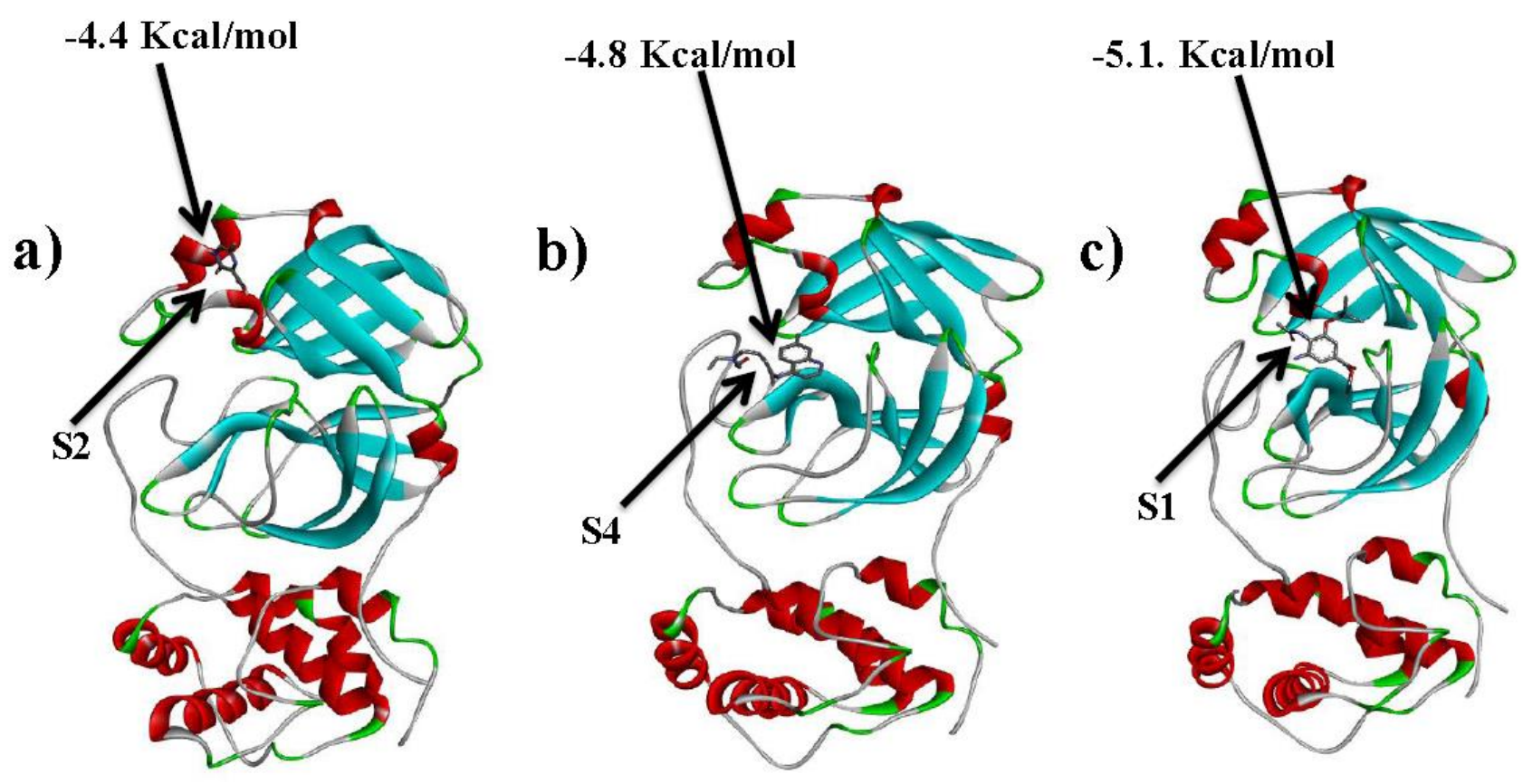

Figure 1: Binding energies and active binding sites for drugs a) $\mathrm{F}, \mathbf{b}) \mathrm{H}$ and c) $\mathbf{O}$ towards protein 6LU7 by individual docking.

The sequential docking mechanism has been used for docking the combination drugs as inhibitors for receptor protein 6LU7. In the present study we have used various combination of drugs. They are: $\mathrm{F}+\mathrm{H}, \mathrm{F}+\mathrm{O}, \mathrm{H}+\mathrm{O}$ and $\mathrm{F}+\mathrm{H}+\mathrm{O}$. Among the combination of two inhibitors, $\mathrm{F}+\mathrm{H}$ combination has showed better binding affinity towards 6LU7 from sequential docking. The binding affinity of combination of two drugs F+H:6LU7complex showed the substantial enhancement in the binding energy $(-5.2$ $\mathrm{Kcal} / \mathrm{mol}$ ) from their individual complexation with 6LU7. Similarly, for the three combination drugs $\mathrm{F}+\mathrm{H}+\mathrm{O}$, further substantial enhancement in the binding affinity $(-5.3 \mathrm{Kcal} / \mathrm{mol})$ was observed towards 6LU7. Also for sequential docking we did not get the favorable interaction of drug combination with the specific mentioned active sites in the combination mode. It may happen due to the fact that proteins are flexible and can be crystallized in multiple conformations resulting in the variation of the side chain orientations of the active residues located in the protein's active sites which could contribute to different binding poses for the combination drugs. The presences of multiple new conformations with new binding sites usually help to predict new combinations of antiviral drugs targeting SARS-CL ${ }^{\text {pro }}$. So, from the results of individual and sequential docking we may conclude that the binding affinity for $\mathrm{F}+\mathrm{H}+\mathrm{O}$ combination is better than $\mathrm{F}+\mathrm{H}, \mathrm{H}+\mathrm{O}$ combinations and individual forms of $\mathrm{F}, \mathrm{H}$ and $\mathrm{O}$. Molecular docking results may predict that combination drug of $\mathrm{F}+\mathrm{H}+\mathrm{O}$ can interact in more aggressively with CoV-2 receptor protein than their mono/dual combination mode. The result of individual docking and 
sequential docking are shown in figure 2. For every best pose, the donor-acceptor surface are shown in figure 3 in 3D and 2D view with their possible hydrogen bonding (Table 3 and SD1).

Table 3: Various interaction parameters for the docked structure of $\mathrm{F}, \mathrm{F}+\mathrm{H}$ and $\mathrm{F}+\mathrm{H}+\mathrm{O}$ with receptor protein 6LU7. Drug Favipiravir represented as F, Hydroxychloroquine represented as $\mathrm{H}$ and Oseltamivir represented as $\mathrm{O}$.

\begin{tabular}{|c|c|c|c|c|c|}
\hline Ligand & $\begin{array}{l}\text { Binding } \\
\text { affinity } \\
\text { (kcal/mol) }\end{array}$ & $\begin{array}{l}\text { Hydrogen bonded interaction (donor - acceptor, } \\
\text { distance in } \AA \text { ) (A:6LU7, drug:ligand) }\end{array}$ & $\begin{array}{l}\text { Dreiding } \\
\text { energy } \\
\text { (ligand) }\end{array}$ & $\begin{array}{l}\text { Dipole } \\
\text { moment } \\
\text { of ligand } \\
\text { (Debye) }\end{array}$ & $\begin{array}{l}\text { Inhibition } \\
\text { Constant( } \\
\text { M) } \\
\boldsymbol{K}_{i}=e^{\Delta G / R T}\end{array}$ \\
\hline $\mathbf{F}$ & -4.4 & $\begin{array}{l}\text { (A:THR24:HN -:F:O, 2.00099) } \\
\text { (A:THR24:HG1 -:F:O,2.30365) } \\
\text { (A:THR25:HN -:F:O,2.82701) } \\
\text { (:F:H -:A:CYS22:O,2.76702) } \\
\text { (:F:H -:A:THR25:OG1, 2.39306) } \\
\text { (:F:H -:A:VAL42:O, 2.80565) } \\
\text { (:F:H -:A:CYS44:O, 2.54365) } \\
\text { (:F:H -:A:ILE43:O,2.72896) }\end{array}$ & 53.0 & 2.437 & $5.9 \times 10^{-4}$ \\
\hline $\mathbf{F}+\mathbf{H}$ & -5.2 & $\begin{array}{l}\text { (A:GLN110:HE21 -:H:N,2.70214) } \\
\text { (A:GLN110:HE2 -:H:N,2.72991) } \\
\text { (:H:H -:A:THR111:O,2.5057) }\end{array}$ & 171.4 & 2.444 & $1.5 \times 10^{-4}$ \\
\hline $\mathbf{F}+\mathrm{H}+\mathrm{O}$ & -5.3 & $\begin{array}{l}\text { (:O:H30 -:A:LYS137:O, 2.4748) } \\
\text { (:O:H31 -:A:LYS137:O,2.26105) } \\
\text { (:O:H32 -:A:GLY138:O, 2.24204) }\end{array}$ & 100.6 & 3.964 & $1.3 \times 10^{-4}$ \\
\hline
\end{tabular}
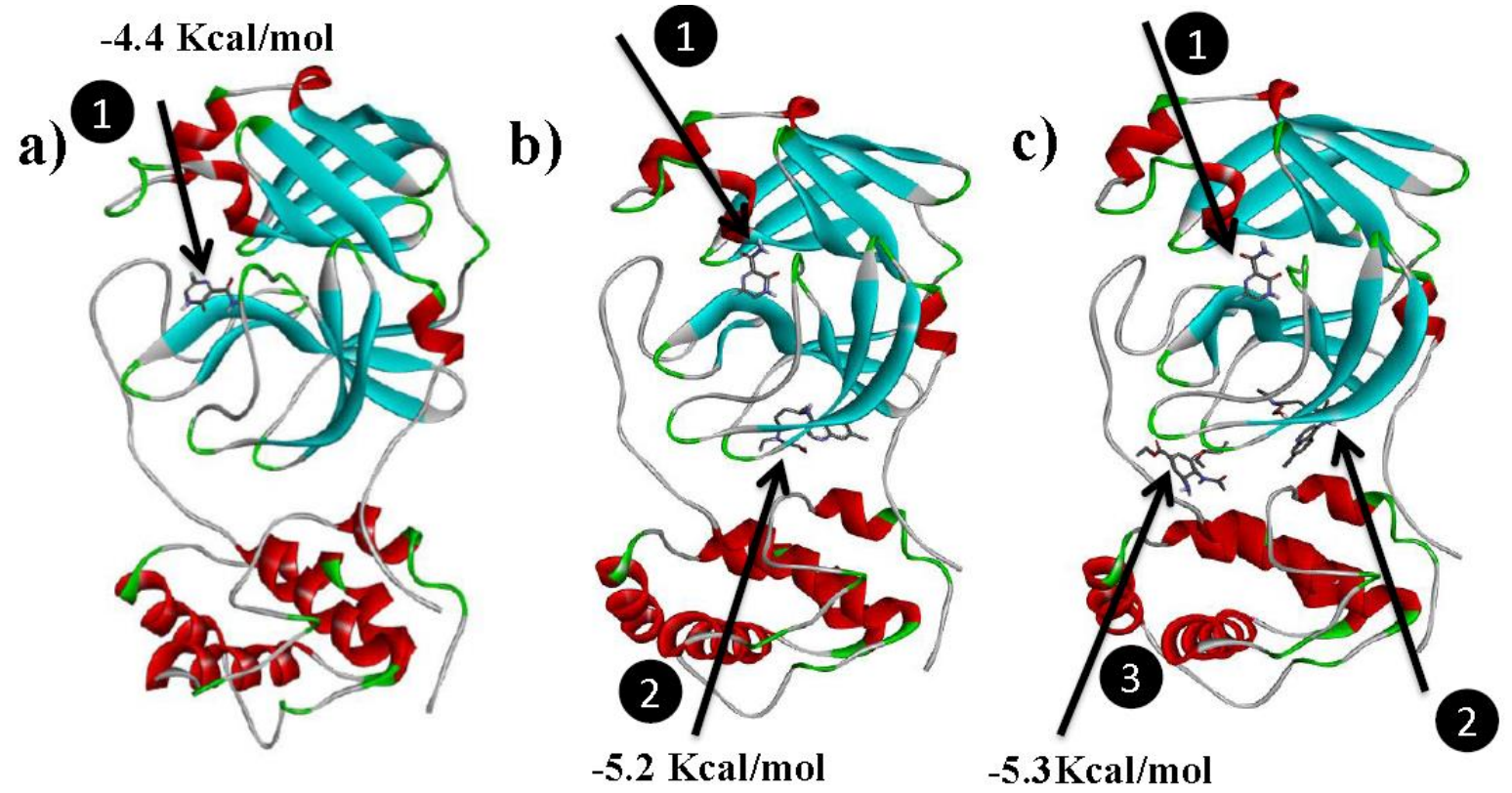

Figure 2: Binding energies and binding sites for drug a) $\mathrm{F}, \mathbf{b}) \mathrm{F}+\mathrm{H}$ and c) $\mathrm{F}+\mathrm{H}+\mathrm{O}$ towards protein 6LU7 by sequential docking. 
The individual protein and ligand shows a different value of dreiding energy. But when the receptor protein and ligand form the complex then they shows the less value of dreiding energy than the individual value. Lowest dreiding energy means the most favorable structure of protein:ligand complex structure [91]. Dipole moment of protein:ligand complex also plays a vital role in identifying the stability of the complexation. Maximum value of dipole moment for a specific complex structure means better stability of the structure between receptor protein and ligand. The values of dipole moment for all ligand with receptor protein (F:6LU7, H:6LU7, O:6LU7, F+H:6LU7, F+H+O:6LU7) are shown in table 3 and SD1. The maximum value of dipole moment (3.964Debye) for $\mathrm{F}+\mathrm{H}+\mathrm{O}: 6 \mathrm{LU} 7$ means the better stability of F+H+O:6LU7 complex structure (Table 3). 


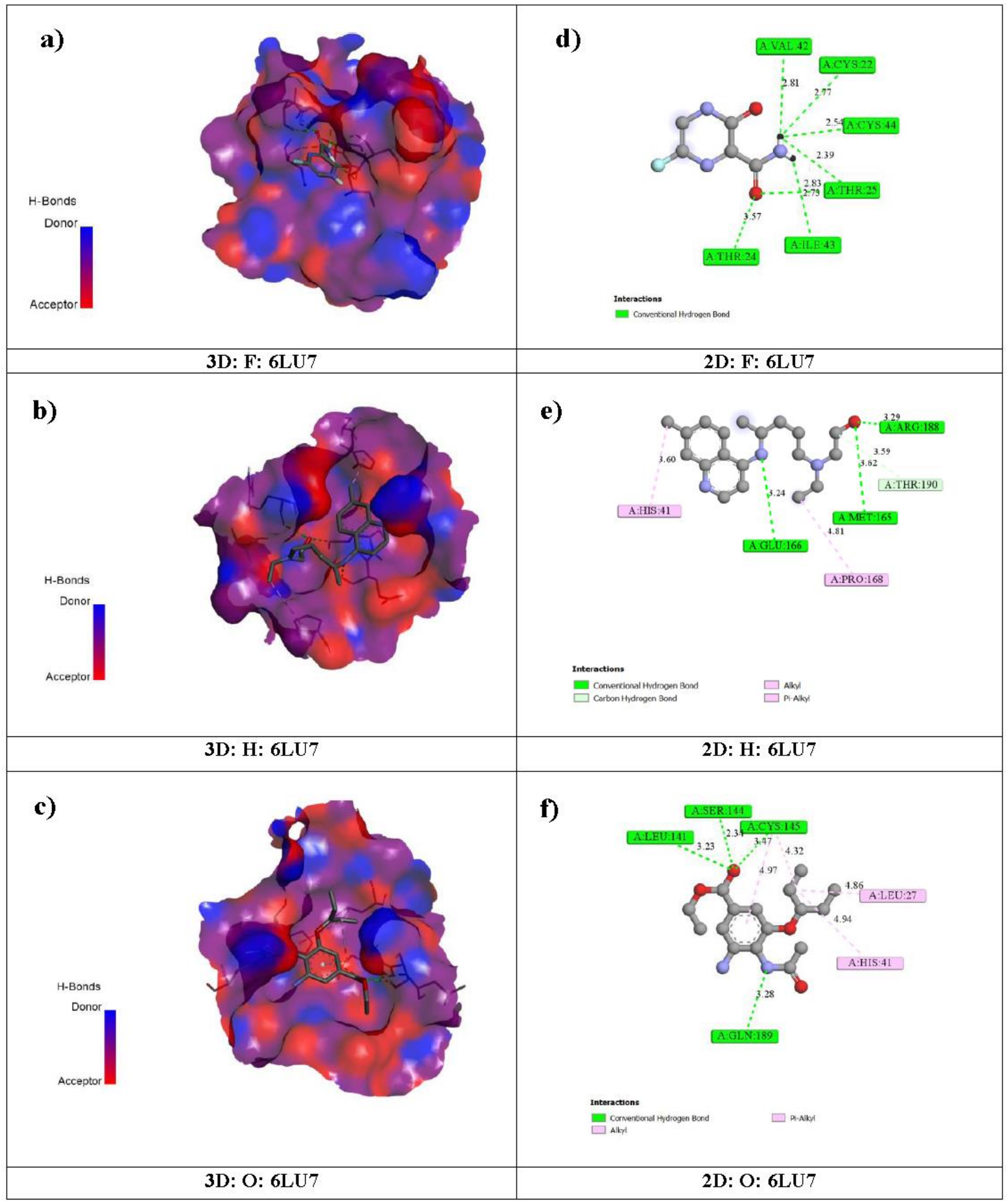

Figure 3: Donor:acceptorsurface for best pose in terms of $\mathrm{H}$-bond interaction a), b), c) F:6LU7,H:6LU7, O:6LU7 d), e), f) Possible types of interaction in pose obtained from F:6LU7, H:6LU7, O:6LU7. 
In the same way the lowest $\mathrm{k}_{i}$ value for the $\mathrm{F}+\mathrm{H}+\mathrm{O}: 6 \mathrm{LU} 7$ complex structure means the highest affinity of combination drugs $\mathrm{F}+\mathrm{H}+\mathrm{O}$ towards host protein 6LU7. Results of molecular docking indicates that $\mathrm{F}+\mathrm{H}+\mathrm{O}$ combination can be easily inhibited into the favorable active site of receptor protein 6LU7 and can easily form a best probable stable complex F+H+O:6LU7 than their mono/dual combination modes. Existence of intermolecular hydrogen bonding between receptor and inhibitor also plays a dominant role for the inhibitor:receptor complex formation. Appearance of hydrogen bonded interactions between $\mathrm{F}+\mathrm{H}+\mathrm{O}$ and $6 \mathrm{LU} 7$ protein residues also validated the possibility of complex formation between $\mathrm{F}+\mathrm{H}+\mathrm{O}$ and 6LU7. Through MD simulation, further we have checked the possibility of existence of various interaction forces needed for the ligand:receptorcomplex formation between ligand inhibitor and receptor protein for various ligand drugs $\mathrm{F}, \mathrm{H}, \mathrm{O}$ in their individual forms and in their combination modes such as $\mathrm{F}+\mathrm{H}, \mathrm{F}+\mathrm{H}+\mathrm{O}$ have been discussed through $\mathrm{MD}$ simulation results in next section.

\subsection{Simulation analysis}

In this study there are many stable complex structures of drug molecules in their individual levels $(\mathrm{F}, \mathrm{H}$, $\mathrm{O})$ and in combinations modes $(\mathrm{F}+\mathrm{O}, \mathrm{F}+\mathrm{H}, \mathrm{H}+\mathrm{O}, \mathrm{F}+\mathrm{H}+\mathrm{O})$ have been studied which were formed in the molecular docking in presence of main $3 \mathrm{CL}^{\text {pro }}$ protease (6LU7). MD simulation bare protein structure and for ligand:protein complex structures carried out for both 0ps-10000ps and for 0 ps-100000 ps time scale variation with a increment of 1 ps to analyze the stability of forming complex structure. The comparison and analyzation of $\mathrm{E}_{\mathrm{pot}}$ of the stabilized structures of protein in its bare state with individually docked ligands compound and also with sequential docked ligands have been done simultaneously (Figure 4). Protein in its bare state has an average $\mathrm{E}_{\mathrm{pot}} \mathrm{Of}-0.3 \times 10^{6} \mathrm{Kcal} / \mathrm{mol}$. The average $\mathrm{E}_{\mathrm{pot}}$ for individual $\mathrm{F}, \mathrm{H}$ and $\mathrm{O}$ and ligands in their combination modes $(\mathrm{F}+\mathrm{H}, \mathrm{F}+\mathrm{H}+\mathrm{O})$ in presence of 6LU7 were obtained as at the order of $-0.1 \times 10^{6} \mathrm{Kcal} / \mathrm{mol}$ (Figure 4). After optimization we can conclude that all the ligand:6LU7 complex structures (individual combination) are equally stable and ready for real MD simulation. Total energy /Enthalpy of each protein: ligand complex structure and in their combination forms were also computed before MD simulation. Total energy for the individual drug $\mathrm{F}, \mathrm{H}$ and $\mathrm{O}$ was computed as $-0.47 \times 10^{5} \mathrm{Kcal} / \mathrm{mol},-0.47 \times 10^{5} \mathrm{Kcal} / \mathrm{mol}$ and $-0.48 \times 10^{5} \mathrm{Kcal} / \mathrm{mol}$ (Table 4, SD6). Also for combination drug, value for total energy was observed for $\mathrm{F}+\mathrm{H}$ and $\mathrm{F}+\mathrm{H}+\mathrm{O}$ as$0.45 \times 10^{5} \mathrm{Kcal} / \mathrm{mol}$ and $-0.59 \times 10^{5} \mathrm{Kcal} / \mathrm{mol}$ (Table 4). Also the values for enthalpy of individual drug $(\mathrm{F}, \mathrm{H}, \mathrm{O})$ and combination drug $(\mathrm{F}+\mathrm{H}, \mathrm{F}+\mathrm{H}+\mathrm{O})$ are shown in table 4 and SD6. Total energy/ enthalpy of the combination drug mode $(\mathrm{F}+\mathrm{H}+\mathrm{O})$ showed the lowest energy of the protein: ligand complex structure 
compared to their individual modes. Existence of lowest energy validated the lowest entropy of the combination $(\mathrm{F}+\mathrm{H}+\mathrm{O})$ system which further satisfies the best stability of the system (Table 4).

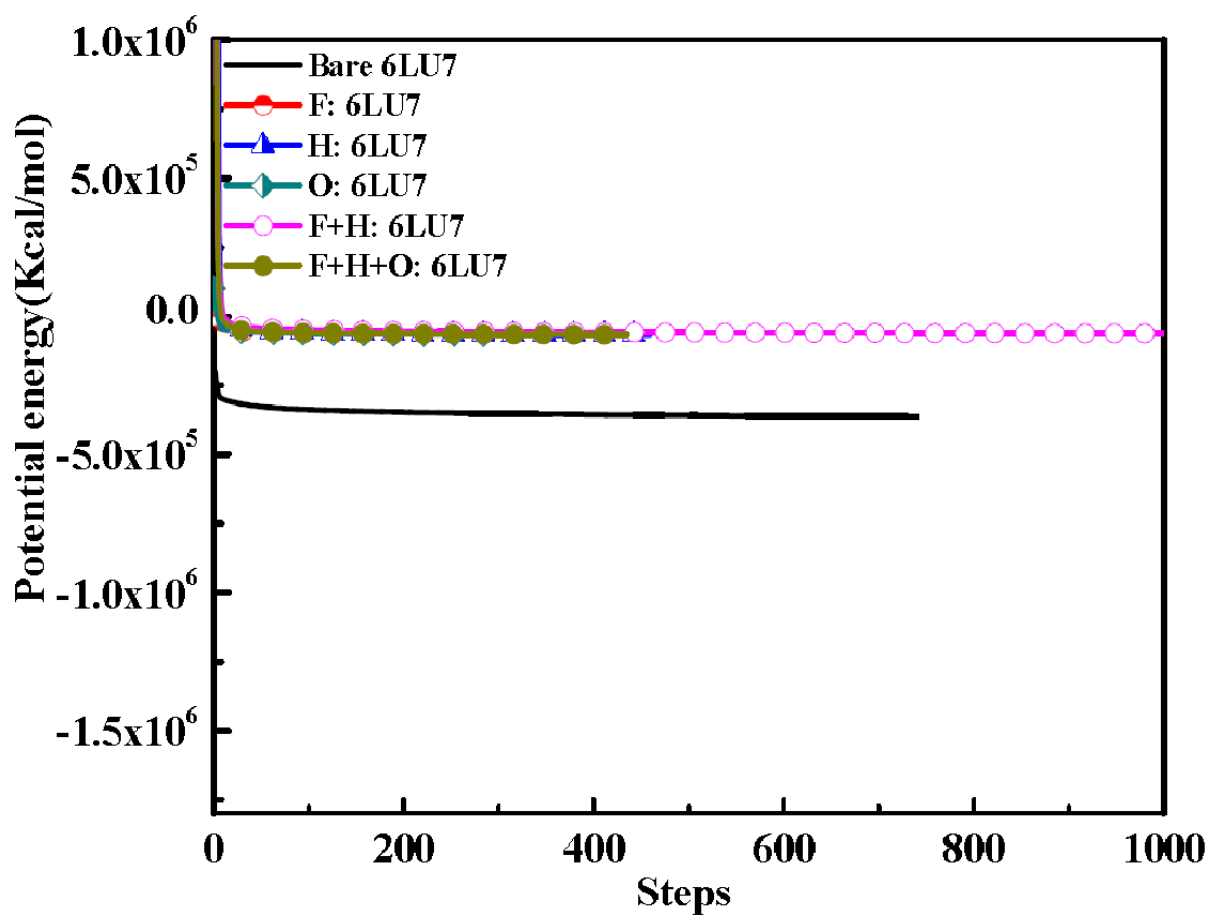

Figure4: Potential energy of receptor 6LU7 and complex structures of $\mathrm{F}, \mathrm{H}, \mathrm{O}, \mathrm{F}+\mathrm{H}$ and $\mathrm{F}+\mathrm{H}+\mathrm{O}$ with 6LU7.

Further, under the equilibrium condition (NVT and NPT) we have verified the stability of each complex structures. The temperature (T), density (D), pressure (P) and volume (V) of each complex structure with varying time trajectory from 0ps to 100ps have been calculated. All computed data for protein in its bare state and ligand:protein complex form showed that the temperature reached to a stable equilibrium state at room temperature $(300 \mathrm{~K})$ within few ps of simulation (SD2a, SD 3a) and sustained the stability through the complete simulation process. The stability of the equilibrated complex structures have been validated by the simulated data of D, P throughout the whole time scale trajectory (SD 2b, c and SD 3b, c). Output for all thermodynamic parameters for protein in its bare state and with all complex formations with possible ligands are shown in Table 4, SD 4. 
Table 4: Data obtained from MD simulations for receptor protein 6LU7 in its bare state and for the F:6LU7, F+H:6LU7 and F+H+O:6LU7 complex structure.

\begin{tabular}{|c|c|c|c|c|c|c|c|c|c|}
\hline \multirow{2}{*}{$\begin{array}{l}\text { S. } \\
\text { No }\end{array}$} & \multirow[t]{2}{*}{ Parameter } & \multicolumn{2}{|c|}{ Bare protease (6LU7) } & \multicolumn{2}{|c|}{ F:6LU7 } & \multicolumn{2}{|c|}{ F+H:6LU7 } & \multicolumn{2}{|c|}{ F+ H+O:6LU7 } \\
\hline & & Mean & Range & Mean & Range & Mean & Range & Mean & Range \\
\hline \multicolumn{10}{|c|}{ MD Simulation Result } \\
\hline 1. & $\begin{array}{l}\text { SR Columbic } \\
\text { Interaction Energy } \\
\text { (Kcal/mol) }\end{array}$ & NA & NA & -11.6 & $0--20$ & -7.1 & $0--10$ & -14.7 & $0--25$ \\
\hline 2. & $\begin{array}{l}\text { SR LJ Interaction } \\
\text { Energy (Kcal/ mol) }\end{array}$ & NA & NA & -20.3 & $0--30$ & -46.8 & $-30--80$ & -31.1 & $-5--20$ \\
\hline 3. & RMSD (nm) & 0.22 & $0.13-0.32$ & 0.25 & $0.10-0.40$ & 0.21 & $0.12-0.29$ & 0.22 & $0.14-0.31$ \\
\hline 4. & Inter H-Bonds & NA & NA & 5 & $0-9$ & 2 & $0-3$ & 3 & $0-4$ \\
\hline 5. & Radius of gyration & 2.18 & $2.13-2.24$ & 2.21 & $2.20-2.21$ & 2.21 & $2.16-2.26$ & 2.18 & $2.12-2.25$ \\
\hline 6. & SASA $\left(\mathrm{nm}^{2}\right)$ & $30-35$ & 33 & $6-10$ & 8 & $6-10.5$ & 8.2 & $6-9$ & 7.5 \\
\hline \multicolumn{10}{|c|}{ MM/PBSA Results } \\
\hline 7. & $\begin{array}{l}\text { Potential Energy } \\
\text { (Kcal /mol) }\end{array}$ & $-0.3 \times 10^{6}$ & $\begin{array}{l}-7.0 \times 10^{5}-- \\
1.3 \times 10^{6}\end{array}$ & $-0.1 \times 10^{6}$ & $\begin{array}{l}-3.4 \times 10^{4}-- \\
2.8 \times 10^{5}\end{array}$ & $-0.1 \times 10^{6}$ & $\begin{array}{l}-3.4 \times 10^{4}-- \\
2.8 \times 10^{5}\end{array}$ & $-0.1 \times 10^{6}$ & $\begin{array}{l}-3.4 \times 10^{4} \\
-- \\
2.8 \times 10^{5}\end{array}$ \\
\hline 8 & $\begin{array}{l}\text { Total } \\
\text { energy }(\mathrm{Kcal} / \mathrm{mol})\end{array}$ & -- & -- & $-0.47 \times 10^{5}$ & -- & $-0.45 \times 10^{5}$ & -- & $-0.59 \times 10^{5}$ & -- \\
\hline 9 & Enthalpy(Kcal/mol) & -- & -- & $-0.47 \times 10^{5}$ & -- & $-0.45 \times 10^{5}$ & -- & $-0.61 \times 10^{5}$ & -- \\
\hline 10. & $\begin{array}{l}\text { Binding } \\
\text { energy }(\Delta G)(\mathrm{Kcal} / \mathrm{mo} \\
\text { l) }\end{array}$ & NA & NA & -4.1 & NA & -29.6 & NA & -51.3 & NA \\
\hline 11. & $\begin{array}{l}\text { Van der Waal } \\
\operatorname{Energy}\left(\Delta \mathbf{E}_{\text {vdw }}\right) \\
(\text { Kcal } / \mathbf{m o l})\end{array}$ & $\mathrm{NA}$ & NA & -0.0026 & $\mathrm{NA}$ & -35.0 & NA & -70.8 & NA \\
\hline 12. & $\begin{array}{l}\text { Electrostatic } \\
\operatorname{Energy}\left(\Delta \mathbf{E}_{\text {elec }}\right)(\mathrm{Kcal} / \\
\text { mol })\end{array}$ & $\mathrm{NA}$ & NA & -0.003 & NA & -2.11 & NA & -11.9 & NA \\
\hline
\end{tabular}

In MD simulation, the factor RMSD is very important. It is used to check the stability of complex structure with respect to the (w.r.t) reference carbon backbone structures of receptor protein 6LU7. A 3D view of RMSD values for carbon backbone complex (F+H+O:6LU7) structure with reference to receptor protein in the whole time trajectory $0-10000 \mathrm{ps}$ is shown in figure 5a. Also the 2D graph of RMSD values for carbon backbone for individual complex structures (F:6LU7, H:6LU7, O:6LU7, $\mathrm{F}+\mathrm{H}: 6 \mathrm{LU} 7$ and $\mathrm{F}+\mathrm{H}+\mathrm{O}: 6 \mathrm{LU7}$ ) with respect to $6 \mathrm{LU7}$ are shown in figure $5 \mathrm{~b}$ for time trajectory 010000ps (Figure 5b, SD 5). Also, for the values of RMSD the 2D graph for 6LU7 in its bare state and individual complex structures $(\mathrm{F}+\mathrm{H}+\mathrm{O}: 6 \mathrm{LU} 7)$ with respect to 6LU7 are shown in inset of figure 5b in time trajectory $0-100 \mathrm{~ns}$ (0 ps to $100000 \mathrm{ps}$ ). From the graph, it is observed for the complex $(\mathrm{F}+\mathrm{H}+\mathrm{O}: 6 \mathrm{LU} 7)$ structure the value of RMSD showed a variation between $0.14-0.31 \mathrm{~nm}$ compared to receptor protein 6LU7 variation $0.13-0.32$, which indicates that possibility of less fluctuation when the ligands are binding with protein (Table 4). Also the result observed for the complex structures (F:6LU7, H:6LU7, O:6LU7, F+H:6LU7) showed a variation between 0.10-0.40, 0.23-0.24, 0.09-0.48, 0.12-0.29 $\mathrm{nm}$ compared to receptor protein 6LU7 variation $0.13-0.32$ again indicates that the less fluctuation in 
every complex structure during binding with receptor protein (Table 4, SD 4). Also the value of RMSD for complex structure $(\mathrm{F}+\mathrm{H}+\mathrm{O}: 6 \mathrm{LU} 7)$ observed in graph varying between $0.18-0.32 \mathrm{~nm}$ which is similar to receptor protein $(0.16-0.30 \mathrm{~nm})$ for the larger time trajectory 0-100 ns (inset Figure 5b). This result is similar to the result observed for the time trajectory 0-10ns. This result showed the better stability of the ligand:protein complex structure by its less fluctuation RMSD value throughout simulation process even in the larger time scale variation.
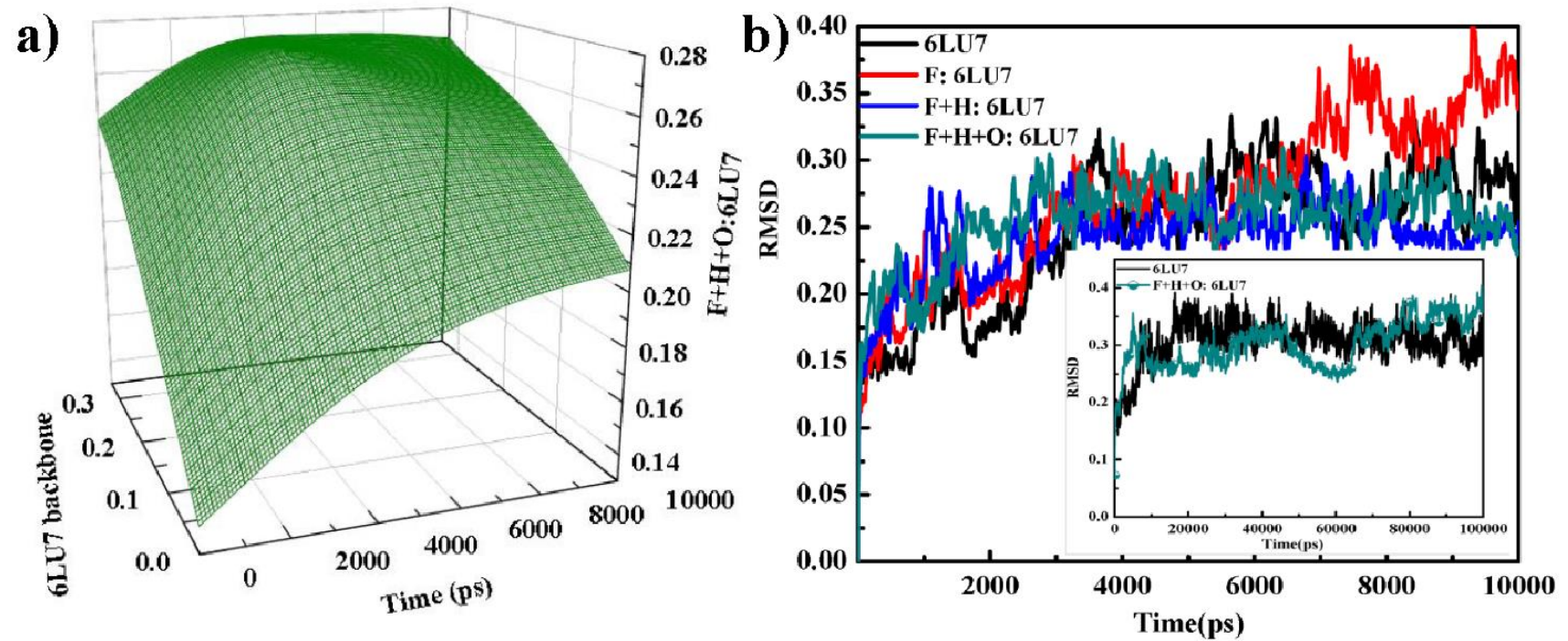

Figure: 5a) Root mean square deviation (RMSD) graphs for bare state of receptor protein 6LU7 and in complex (F+H+O:6LU7) with 6LU7 3D view up to 10000ps and b) 2D for complex (F:6LU7,F+H:6LU7 and F+H+O:6LU7) view up to 10000ps inset (RMSD graph for bare state of receptor protein 6LU7 and complex (F+H+O:6LU7) view up to $100000 \mathrm{ps}$ ).

The average RMSD value for the $\mathrm{F}+\mathrm{H}+\mathrm{O}: 6 \mathrm{LU} 7(0.22 \mathrm{~nm})$ and host protein $(0.22 \mathrm{~nm})$ is same which confirms the best stable complex structure in combination mode. Also the flatness observed in 3D contour suggest that host protein does not show any significant change in presence of $\mathrm{F}+\mathrm{H}+\mathrm{O}$ combination ligand during time resolved simulation which confirmed the better stability of $\mathrm{F}+\mathrm{H}+\mathrm{O}$ :6LU7 complexation compared to other complexations either in combination modes or in individual forms (Figure 5a). Similarly, in the case of RMSF, among all the complex structures F:6LU7, H:6LU7, O:6LU7, F+H:6LU7 and F+H+O:6LU7 we observed less fluctuation between the receptor and inhibitors in all complex structures. Perfect similarity in RMSF values confirmed that the complex structure does not affected the protein backbone (Figure 6a, SD 6a). From all the graph the RMSF value 
for $\mathrm{F}+\mathrm{H}+\mathrm{O}: 6 \mathrm{LU} 7$ is exactly same with the host protein means very less fluctuations in the docked structure (Figure6a). The radius of gyration $\left(\mathrm{R}_{\mathrm{g}}\right)$ tells us about the compressed nature of a complex structure or backbone receptor protein [92]. Variation of $R_{\mathrm{g}}$ values throughout the total-time trajectory (0 ps to 10000 ps and 0-100000ps) showed that all complex structures F:6LU7, H:6LU7, O:6LU7, $\mathrm{F}+\mathrm{H}: 6 \mathrm{LU} 7$ and $\mathrm{F}+\mathrm{H}+\mathrm{O}: 6 \mathrm{LU} 7$ showed a quite stable and compressed structures are shown in table 4 (Figure 6b, SD 6b). Rgof $\mathrm{F}+\mathrm{H}+\mathrm{O}: 6 \mathrm{LU} 7$ and bare 6LU7 show a perfect match having an average value of $2.18 \mathrm{~nm}$ with a fluctuation between 2.13-2.24 nm (Figure6b, Table 4). The obtained value of $\mathrm{R}_{\mathrm{g}}$ for complex structure $(\mathrm{F}+\mathrm{H}+\mathrm{O}: 6 \mathrm{LU} 7)$ varying between $2.09-2.19 \mathrm{~nm}$ in whole time trajectory 0-100000ps (0-100ns) (inset Figure 6b), which is similar to the result observed from the time trajectory 0-10000ps. This result also shows that the $\mathrm{F}+\mathrm{H}+\mathrm{O}: 6 \mathrm{LU} 7$ complex structure is quite stable and compressed structure immediate from its formation.
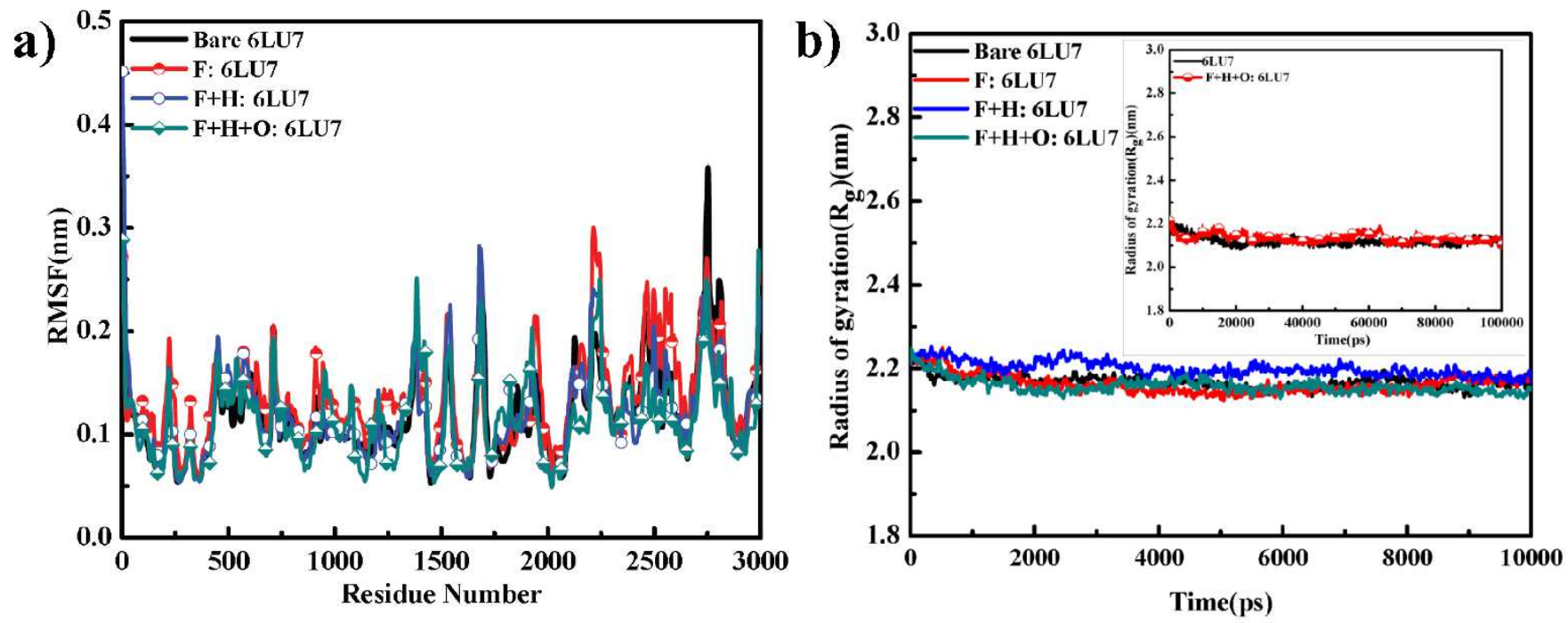

Figure: 6a) RMSF for bare state 6LU7 and of complex (F:6LU7, F+H:6LU7 and F+H+O:6LU7) structure, b) $\mathrm{R}_{\mathrm{g}}$ for bare state 6LU7 and of complex (F:6LU7, F+H:6LU7 and F+H+O:6LU7)structure in time trajectory $(0-10000 \mathrm{ps})$ inset $\left(\mathrm{R}_{\mathrm{g}}\right.$ for complex $(\mathrm{F}+\mathrm{H}+\mathrm{O}: 6 \mathrm{LU} 7)$ structure in time trajectory $(0-100000$ ps).

We have also computed solvent Accessible Surface area (SASA) which tells about the area of receptor contact to the solvents. The larger value of SASA means that more of the drug is inserted into the water. And smaller the value of SASA means that more of the drug is covered by the protein means better complexation. The SASA area for bare receptor protein and for all complex structures F:6LU7, H:6LU7, O:6LU7, F+H:6LU7 and F+H+O:6LU7 (Figure 7d, SD 7) shown in table 4. The SASA value for bare protein was calculated between $30-35 \mathrm{~nm}^{2}$ with a $33 \mathrm{~nm}^{2}$ mean value however, in presence of different 
ligand drug molecules, for all inhibitor:6LU7 complexes the SASA values were observed between 6-10 $\mathrm{nm}^{2}$ which satisfied the possibility of better complexation of all drugs with receptor 6LU7. Among all other drug combination for $\mathrm{F}+\mathrm{H}+\mathrm{O}$ :6LU7 complex, the lowest value for SASA was observed between 6-9 $\mathrm{nm}^{2}$ with $7.5 \mathrm{~nm}^{2}$ mean value (Figure 7d) which validate the best complexation possibility in time trajectory 0-10000ps. For simulation in larger time trajectory $(0-100000 \mathrm{ps})$, similar SASA was observed between 6-9 $\mathrm{nm}^{2}$ with $7.5 \mathrm{~nm}^{2}$ mean value (inset Figure $7 \mathrm{~d}$ ) which validate the best complexation possibility for $\mathrm{F}+\mathrm{H}+\mathrm{O}: 6 \mathrm{LU} 7$ complex.
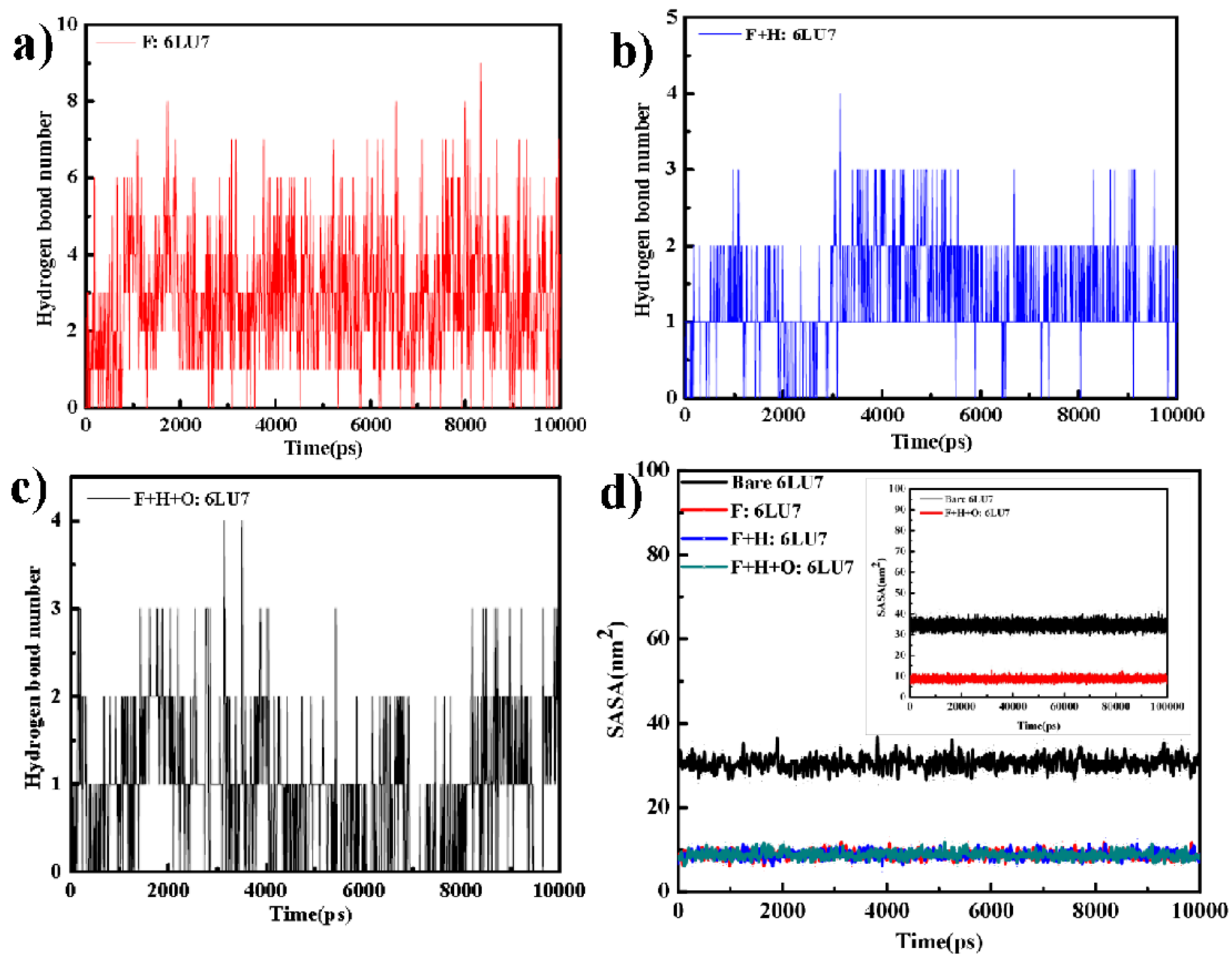

Figure 7 a), b), c): Intermolecular Hydrogen bond numbers for complex (F:6LU7, F+H:6LU7, $\mathrm{F}+\mathrm{H}+\mathrm{O}$ :6LU7) structure for the total time trajectory, d) SASA area for protein 6LU7 in its bare state and for complex (F:6LU7, F+H:6LU7, F+H+O:6LU7) structure in time trajectory 0-10000ps inset ( SASA area for protein in its bare state and complex $(\mathrm{F}+\mathrm{H}+\mathrm{O}: 6 \mathrm{LU} 7)$ structure in time trajectory 0 100000ps). 
Stability of ligand:receptor protein complex structure is dependent on the contribution of nonbonded interactions. Intermolecular nonbonded hydrogen bonded interaction between ligand and receptor protein plays a dominant role to define the stability of complex structure. For present simulation a $3.5 \AA$ cut-off condition is used to identify the proper nonbonded hydrogen bonded interaction. In the present study, the number of hydrogen bonded interactions for different complex combinations F:6LU7, $\mathrm{F}+\mathrm{H}: 6 \mathrm{LU} 7, \mathrm{~F}+\mathrm{H}+\mathrm{O}: 6 \mathrm{LU} 7$ were observed to be varying between 0 to 8,0 to 3 and 0 to 3 . The obtained numbers of intermolecular hydrogen bonded interactions between inhibitor:receptor for all combination drugs through MD simulations were perfectly matched with the molecular docking results (Table 4 , Figure $7 \mathrm{a}, \mathrm{b}, \mathrm{c})$.
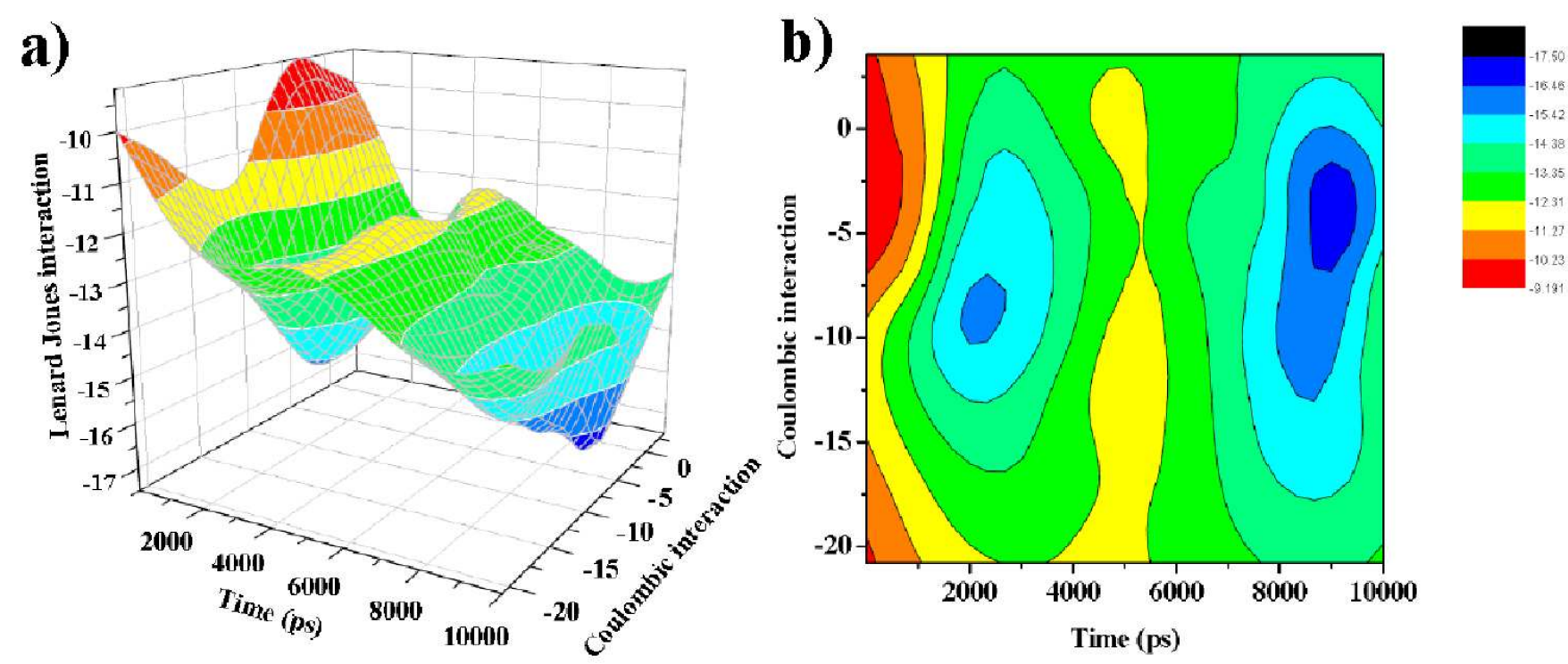

Figure 8 a): For F+H+O:6LU7 complex: a)Variation of Coulombic interaction energy and Lenard Jones interaction energy with respect to time b) attached with color contour representation with specific color coding.

Nonbonded interaction energy also plays a very important role to validate the strength of interaction between a ligand and receptor protein in ligand:protein complex structure. In the present study, for all complex structures F:6LU7, H:6LU7, O:6LU7, F+H:6LU7 and F+H+O:6LU7, we have observed a variation of short-range Coulombic interaction (Coul-SR) energy and Lennard Jones (LJ-SR) energy (Table 4) over the full-time trajectory. For all complex structures Lennard-Jones interaction has shown higher effect on the binding affinity than the coulombic interaction. For F+H+O:6LU7 complexation higher effect of Lennard-Jones interaction energy $(-31.1 \mathrm{Kcal} / \mathrm{mol})$ compared to 
Coulombic interaction $(-14.7 \mathrm{Kcal} / \mathrm{mol})$ is represented by $3 \mathrm{D}$ view and with color contour representation of LJ-SR energy and Coul-SR energy with respect to the whole time trajectory (Figure 8b). In Figure 8, a 3D graph of Coulombic interaction energy and Lenard Jones interaction energy with respect to time, and also with color contour shows a decrement in Coulombic and Lenard Jones interaction energy after time interval $\sim 4 \mathrm{~ns}$ and further decrement after $\sim 6 \mathrm{~ns}$ of the full time scale. The decrement in different interaction energies with time validate the stability of specific protein:ligand complex structure. The data can be comparable with other already reported drug lopinavir. The LJ-SR energy for SARS-CoV-2 M ${ }^{\text {pro }}$ protein inhibitor with lopinavir is $-30 \mathrm{Kcal} / \mathrm{mol}$ and Coul-SR energy is $-12.81 \mathrm{Kcal} / \mathrm{mol}$ which is larger than the F+H+O:6LU7 complex structure[66].So from this we conclude that F+H+O:6LU7 complex structure is more stable and suitable than 5FRS:Lopinavir complex structure.

To find the presence stronger ligand binding affinities towards receptor protein we have applied the MM/PBSA method. The present study is to check the binding affinities of different inhibitor combinations of $\mathrm{F}, \mathrm{H}, \mathrm{O}, \mathrm{F}+\mathrm{H}$ and $\mathrm{F}+\mathrm{H}+\mathrm{O}$ with receptor protein 6LU7 the above mentioned $\mathrm{E}_{\mathrm{vdw}}$ and Eelectrostatic have been computed and are shown in table 4. For nonbonded complexation process between inhibitor and receptor system, $\mathrm{E}_{\mathrm{vdw}}$ component plays an vital role because it describes the existence of nonbonded interaction in terms of dispersion, repulsion, and induction forces. Electrostatic $_{\text {component may }}$ arise due to the unequal distribution of charges between the two components of the complex structure. For ligand:protein complex formation Eelectrostatic usually does not show any significant role since for ligand:protein nonbonded complex structure there is no major role of charge variation. So greater the value of $E_{\mathrm{vdw}}$ means the better stability of complex structure and so the good binding affinity between inhibitor and receptor. Among all inhibitor combinations $(\mathrm{F}, \mathrm{H}, \mathrm{O}, \mathrm{F}+\mathrm{H}$ and $\mathrm{F}+\mathrm{H}+\mathrm{O})$, the best binding affinity was observed for $\mathrm{F}+\mathrm{H}+\mathrm{O}: 6 \mathrm{LU} 7$ with the appearance of maximum value of $\mathrm{E}_{\mathrm{vdw}}(-70.8 \mathrm{Kcal} / \mathrm{mol})$ (Table 4). Molecular docking only predicts the binding energy of the protein:ligand complex. The nonbonding interaction energies of the binding region for the complex formation is generally indicated by the $\Delta \mathrm{G}$ values. $\Delta \mathrm{G}$ depends on Energy in vacuum, Nonpolar solvation energy and Polar solvation energy for complex structure. The average MM/PBSA free binding energy $\left(\Delta \mathrm{G}_{\mathrm{bind}}\right)$ of individual complex structures F:6LU7, H:6LU7, O:6LU7 and F+H:6LU7 were obtained as -4.1, -49.4, -6.2 and $29.6 \mathrm{Kcal} / \mathrm{mol}$. Whereas the average $\Delta \mathrm{G}_{\text {bind }}$ for $\mathrm{F}+\mathrm{H}+\mathrm{O}: 6 \mathrm{LU} 7$ was obtained as $-51.3 \mathrm{Kcal} / \mathrm{mol}$ (Table 4 ). The variation of all parameters (energy in vacuum, nonpolar and polar solvation energies) needed for $\Delta \mathrm{G}$ computation are described in figure9and table 4. Results showed that the decrement of polar energy is more than nonpolar solvation energy. Lowest value of polar solvation justifies the better stability of 
the probe complex structure.Variation of total binding energy for F:6LU7, H:6LU7, O:6LU7, $\mathrm{F}+\mathrm{H}: 6 \mathrm{LU} 7$ and $\mathrm{F}+\mathrm{H}+\mathrm{O}: 6 \mathrm{LU} 7$ over the time trajectory (0-10 ns) also validate the best binding affinity for the combination $\mathrm{F}+\mathrm{H}+\mathrm{O}$ towards the receptor protein 6LU7 by its lowest value throughout the simulation process. Computed lowest value of $\Delta \mathrm{G}_{\text {bind }}$ for $\mathrm{F}+\mathrm{H}+\mathrm{O}: 6 \mathrm{LU} 7(-51.3 \mathrm{Kcal} / \mathrm{mol})$ complex structure proved the possibility of best complex formation for the combination drug $\mathrm{F}+\mathrm{H}+\mathrm{O}$ with $3 \mathrm{CL}^{\text {pro }}$ protease 6LU7. From the results of $\Delta \mathrm{G}_{\text {bind }}$ we can conclude that combination drug $\mathrm{F}+\mathrm{H}+\mathrm{O}$ strongly binds with receptor 6LU7 protein and shows beststability among all other individual and combination drugs. Similarity of computed binding energy of F+H+O:6LU7 complex structure for larger time scale (100ns) and lower time scale (10 ns) validated the stability of complex structure immediate after its formation for the combination drug $\mathrm{F}+\mathrm{H}+\mathrm{O}$ with $3 \mathrm{CL}^{\text {pro }}$ protease $6 \mathrm{LU7}$.

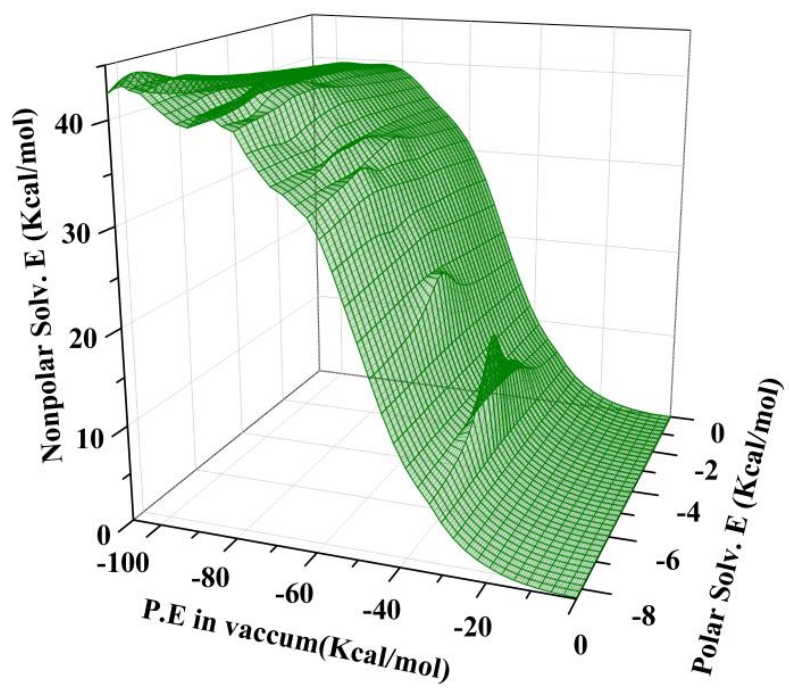

Figure 9 :Relation between energy in vacuum, Polar solvation energy, Nonpolar solvation energy for complex structure $\mathrm{F}+\mathrm{H}+\mathrm{O}: 6 \mathrm{LU} 7$.

In the present study the MD simulation results also validated that repurposing of combination drug $\mathrm{F}+\mathrm{H}+\mathrm{O}$ can make an remarkably stable complex in its triple state combination mode with SARS-CoV-2 protein (6LU7) after binding to the active sites of this protein. The uniqueness of $\mathrm{F}+\mathrm{H}+\mathrm{O}$ combination is justified by its best binding affinity in comparison with their mono $(\mathrm{F}, \mathrm{H}, \mathrm{O})$ or dual combination $(\mathrm{F}+\mathrm{H}$, $\mathrm{H}+\mathrm{O}, \mathrm{F}+\mathrm{O})$ modes towards receptor protein. All other simulated parameters like RMSD, RMSF, $\mathrm{R}_{\mathrm{g}}$, SASA energy validated the same result. 


\section{Conclusion}

Repurposing of combination drugs have already proved their effectiveness to combat against many viral diseases like HIV, Ebola and against other coronaviruses earlier. For the present study we have tried to recognize the mechanism of action of some combination drugs by repurposing some common antiviral and antibiotic drugs as Favipiravir, Hydroxychloroquine and Oseltamivir against COVID-19. The properties like physiochemical, medical chemistry and pharmacokinetics from ADME analysis have found a strong inhibitory opportunity of F, H, O towards SARS-CoV-2 protein $3 \mathrm{CL}^{\text {pro }}$. The results of molecular docking validated the stronger binding affinity of combination drug: $\mathrm{F}+\mathrm{H}+\mathrm{O}$ inhibition towards $\mathrm{CoV}-2$ virus $(-5.3 \mathrm{Kcal} / \mathrm{mol})$ compared to other combination like $\mathrm{F}+\mathrm{O}, \mathrm{F}+\mathrm{H}$ or their individual inhibition like F, H, O. Existence of lowest inhibition constant $\left(1.3 \times 10^{-4} \mathrm{M}\right)$ also established the possibility of better complexation of $\mathrm{F}+\mathrm{H}+\mathrm{O}$ with $6 \mathrm{LU} 7$ protease. Different thermodynamical parameters $\left(\mathrm{E}_{\text {pot }}, \mathrm{T}, \mathrm{V}, \mathrm{D}\right.$, interaction energies, $\mathrm{R}_{\mathrm{g}}, \Delta \mathrm{G}_{\mathrm{bind}}, \mathrm{SASA}$ energy, ) obtained by Molecular dynamics simulations also confirmed the stability of best complex structure formation between $\mathrm{F}+\mathrm{H}+\mathrm{O}$ combination and $\mathrm{CoV}-2$ protein (6LU7) immediately after they interacted. MD simulation data for the whole time scale (0-100ns) validated the stability of the for $\mathrm{F}+\mathrm{H}+\mathrm{O}: 6 \mathrm{LU} 7$ complex structure. The perfect closeness of average RMSD between $\mathrm{F}+\mathrm{H}+\mathrm{O}: 6 \mathrm{LU7}(0.22 \mathrm{~nm})$ and host protein $(0.22 \mathrm{~nm})$ confirmed the total inheritance of proposed combination drug inside host protein. Above result has been further verified by the RMSF variation data which clearly showed that $\mathrm{F}+\mathrm{H}+\mathrm{O}: 6 \mathrm{LU} 7$ complex structure does not affected the protein backbone. Lowest SASA energy for F+H+O:6LU7 complex $\left(7.5 \mathrm{~nm}^{2}\right)$ also validated the best stability of $\mathrm{F}+\mathrm{H}+\mathrm{O}$ combination. The stability of $\mathrm{F}+\mathrm{H}+\mathrm{O}$ combination as complex with 6LU7 was further verified by the lowest value of $\Delta \mathrm{G}_{\text {bind }}(-51.3 \mathrm{Kcal} / \mathrm{mol})$ compared to all other combination and individual forms. By analyzing all the in-silico results obtained from molecular docking and MD simulations we can definitely conclude that repurposing of our proposed antiviral antibiotic drug combination: Favipiravir + Hydroxychloroquine + Oseltamivir has established its strong candidature to be used as a promising potential inhibitor for targeting SARS-CoV-2 virus. We have recommended that Our in-silico results have the strong candidature of combination drugs Favipiravir, Hydroxychloroquine and Oseltamivir as a potential lead inhibitor for targeting SARS-CoV-2 infections. 


\section{Compliance with Ethical Standards}

5.1 Disclosure of potential conflicts of interest: The authors Dr. Papia Chowdhury and Pooja declare that they have no known competing financial interests or personal relationships that could have appeared to influence the work reported in this paper.

5.2 Research involving human participants and/or animals: This article does not contain any studies with human participants or animals performed by any of the authors.

5.3 Informed consent: Informed consent was obtained from all individual participants included in the study.

\section{References}

[1]Wang D, Hu B, Hu C, Zhu F, Liu X, Zhang J, Wang B, Xiang H, Cheng Z, Xiong Y, Zhao Y, Li Y, Wang X, Peng Z. Clinical characteristics of 138 hospitalized patients with 2019 novel coronavirus-infected pneumonia in Wuhan, China. JAMA. 2020; 323(11):1061. https://doi.org/10.1001/jama.2020.1585.

[2]Guan W-j, Ni Z-y, Hu Y, Liang W-h, Ou C-q, He J-x, Liu L, Shan H,Lei C-1, Hui DSC, Du B, Li L-j, Zeng G, Yuen K.-Y, ChenR-c, Tang C-1, Wang T, Chen P-y, Xiang J, Zhong N-s. Clinical characteristics of Coronavirus disease 2019 in China. The New England Journal of Medicine. 2020:382(18):1708-1720. https://doi.org/10.1056/NEJMoa2002032.

[3]Keil R,Ali SH. The avian flu: some lessons learned from the 2003 SARS outbreak in Toronto. Area. 2006; 38(1):107-109.

[4]Rota PA, Oberste MS, Monroe SS, Nix WA, Campagnoli R, Icenogle JP, Pe naranda S, Bankamp B, Maher K, Chen M-H, Tong S, Tamin A, Lowe L, Frace M, DeRisi JL, Chen Q, Wang D, Erdman DD, Peret TCT, et al. Characterization of a novel coronavirus associated with severe acute respiratory syndrome, Science. 2003; 300 (5624): 1394-1399. https://doi.org/10.1126/ science.1085952.

[5]Su S, Wong G, Shi W, Liu J, Lai AC, Zhou J, et al. (2016). Epidemiology, genetic recombination, and pathogenesis of coronaviruses, Trends Microbiol, 24, 6490-502. https://doi.org/10.1016/j.tim.2016.03.003.

[6]Huang C, Wang Y, Li X, Ren L, Zhao J, Hu Y, et al. Clinical features of patients infected with 2019 novel coronavirus in Wuhan, China.Lancet. 2020; 395: 497-506.

[7] https://www.who.int.

[8]Rothe C, Schunk M, Sothmann P, Bretzel G, Froeschl G, Wallrauch C, ZimmerT, Thiel V, Janke C, Guggemos W, Seilmaier M, Drosten C, Vollmar P, Zwirglmaie K, Zange S, WeOlfel, Hoelscher, M. Transmission of 2019-nCoV infection from an asymptomatic contact in Germany, New England. Journal of Medicine. 2020; 382(10):970-971. https://doi.org/10.1056/NEJMc2001468.

[9]Furukawa NW, Brooks JT, Sobel J. Evidence supporting transmission of severe acute respiratory syndrome coronavirus 2 while presymptomatic or asymptomatic.Emerg. Infect. Dis. 2020;26(7).https://doi.org/10.3201/eid2607.201595. 
[10] Chunyang Li, et al.Asymptomatic and human-to-human transmission of SARS-CoV-2 in a 2family cluster. Xuzhou, China.Emerg. Infect. Dis. 2020;26(7):16261628.https://doi.org/10.3201/eid2607.200718.

[11] Ghinai I, et al. First known person-to-person transmission of severe acute respiratory syndrome coronavirus 2 (SARS-CoV-2) in the USA. The Lancet. 2020; 395(10230):1137-1144, https://doi.org/10.1016/S0140-6736(20)30607-3.

[12] Woo PCY, Lau SKP, Chu C-m, Chan K-h, Tsoi H-w, Huang Y, Wong BHL, Poon RWS, Cai JJ,Luk W-k, Poon LLM, WongSSY, Guan Y, Peiris JSM, Yuen KY. Characterization and complete genome sequence of a novel coronavirus, coronavirus HKU1, from patients with pneumonia. Journal of Virology. 2005; 79(2):884-895. https://doi.org/10.1128/JVI.79.2.884$\underline{895.2005}$.

[13] Gorden DE, GwendolynMJ, Bouhaddou M. A SARS-CoV-2- human protein-protein interaction map reveals drug targets and potential drug-repurposing. 2020.bioRxiv. https://doi.org/10.1101/2020.03.22.002386.

[14] Priyadarsini S, PandaS, Singh R, BeheraA], Biswal] P], Mech] P], Ramaiyan] K. In silico structural delineation of nucleocapsid protein of SARS-CoV-2. Journal of Entomology and Zoology Studies. 2020; 8(2): 06-10.

[15] Heidary F, Gharebaghi R. Ivermectin: a systematic review from antiviral effects to COVID-19 complementary regimen. The Journal of Antibiotics. 2020; 73:593-602.

[16] Muradrasoli S, Balint A, Wahlgren J, Waldenstrom J, Belak S, Blomberg J, Olsen, B. Prevalence and Phylogeny of Coronaviruses in Wild Birds from the Bering Strait Area (Beringia). PLoS ONE. 2010; 5(10): e13640. doi:10.1371/journal.pone.0013640.

[17] Jin Z, Du X, Xu Y, Deng Y, Liu M, ZhaoY, Zhang B, Li X, Zhang L, Peng C, Duan Y, Yu J, WangL, Yang K, Liu F, Jiang R, Yang X, YouT, Liu X, YangH. Structure of M $^{\text {pro }}$ from COVID19 virus and discovery of its inhibitors. Nature. 2020; 582(7811) 289-293. https://doi.org/10.1038/s41586-020-2223-y.

[18] Velavan TP, MeyerCG. The COVID-19 epidemic. Tropical Medicine \& International Health: TM \& IH. 2020; 25(3): 278-280. https://doi.org/10.1111/tmi.13383.

[19] Ortega JT, Serrano ML, PujolFH, Rangel HR. Role of changes in SARS-COV-2 spike protein in the interaction with the human ACE2 Receptor: an in silico analysis. EXCLI Journal. 2020; 19: 410-417. http://dx.doi.org/10.17179/excli2020-1167.

[20] WHO Solidarity Trial Consortium. Repurposed antiviral drugs for COVID-19-interim WHO SOLIDARITY trial results. New England journal of medicine. 2021; 384(6): 497-511.

[21] ChowdhuryP. In silico investigation of phytoconstituents from indian medicinal herb 'Tinospora Cordifolia (Giloy)' against SARS-CoV-2 (COVID-19) by molecular dynamics approach. J. Biomol. Struct. Dyn. 2020. https://doi.org/10.1080/ 07391102.2020.1803968.

[22] Yang Y. Use of herbal drugs to treat COVID-19 should be with caution. The Lancet. 2020; 395(10238): 1689-1690.

[23]Zhou S, Huang G. Synthesis, anti-malaria and anti-bacterial activities of marine alkaloids. Chemical Biology \& Drug Design. 2021.

[24] Chang C, Lo SC, Wang YS, Hou MH. Recent insights into the development of therapeutics against coronavirus diseases by targeting N protein. Drug Discovery Today. 2016; 21(4): 562572. 
[25] Grein J, Ohmagari N, Shin D, Diaz G, Asperges E, Castagna A, Feldt T. Compassionate use of remdesivir for patients with severe Covid-19. N. Engl. J. Med. 2020;1-10, https://doi.org/10.1056/NEJMoa2007016.

[26] Singh, UT, Parida S, Lingaraju CM, Kesavan M, Kumar D, Singh KR. Drug repurposing approach to fght COVID-19. Pharmacological Reports. 2020. https://doi.org/10.1007/s43440-02000155-6.

[27] Suryapad P, Chi TH, LeeS. Dietary therapy and herbal medicine for COVID-19 prevention: a review and perspective. J. Tradit. Complement. Med. 2020; 10(4): 420-427.

[28] He Y, Xiao G, Yu G, Song Q, Zhang H, Liu Z, Tan Z, Deng Y. 2-(3-Hydroxybenzyl) benzo [d] isothiazol-3 (2H)-one Mannich base derivatives as potential multifunctional anti-Alzheimer's agents. Medicinal Chemistry Research. 2021;30(6):1249-64.

[29] Chowdhury P, Pathak P. Neuroprotective Immunity by Essential Nutrient "Choline" for the Prevention of SARS CoV2 Infections: An In Silico Study by Molecular Dynamics Approach. Chemical Physics Letters. 2020; 761: 138057.doi: https://doi.org/10.1016/j.cplett.2020.138057.

[30] Dong PL, Li Z, Teng CL, Yin X, Cao XK, HanH. Syntheses and neuroprotective effects evolution of oxymatrine derivatives as anti-Alzheimer's disease agents. Chemical Biology \& Drug Design. 2021.

[31] Baron S, Fons M, Albrecht T. Viral Pathogenesis. In: Baron S, editor. Medical Microbiology. 4th edition. Galveston (TX): University of Texas Medical Branch at Galveston, Chapter 45. 1996. Available from: https://www.ncbi.nlm.nih.gov/books/NBK8149/.

[32] Fried MW, Shiffman ML, Reddy KR, Smith C, Marinos G, Gonçales Jr FL, Craxi A. Peginterferon alfa-2a plus ribavirin for chronic hepatitis C virus infection. New England Journal of Medicine. 2002; 347(13): 975-982.

[33] Elfiky AA, Ribavirin, Remdesivir, Sofosbuvir, Galidesivir, and Tenofovir against SARSCoV-2 RNA dependent RNA polymerase (RdRp): A molecular docking study. Life Sciences. 2020; 253:117592. https://doi.org/10.1016/j.lfs.2020.117592.

[34] Cao YC, Deng QX, Dai SX. Remdesivir for severe acute respiratory syndrome coronavirus 2 causing COVID-19: An evaluation of the evidence. Travel medicine and infectious disease. 2020; 35:101647. https://doi.org/10.1016/j.tmaid.2020.101647.

[35] Costanzo M, Giglio MARD, RovielloGN. SARS-CoV-2: Recent Reports on Antiviral Therapies Based on Lopinavir/Ritonavir, Darunavir/Umifenovir, Hydroxychloroquine, Remdesivir, Favipiravir and other Drugs for the Treatment of the New Coronavirus. Current Medicinal Chemistry. 2020; 27: 4536-4541. DOI: 10.2174/0929867327666200416131117.

[36] Kapoor G, Saigal S, Elongavan A. Action and resistance mechanisms of antibiotics: A guide for clinicians. J Anaesthesiol Clin Pharmacol. 2017; 33(3):300-305. doi:10.4103/joacp.JOACP_349_15.

[37] Grant, Juliana S, et al. Doxycycline prophylaxis for bacterial sexually transmitted infections. Clinical Infectious Diseases. 2020; 70(6):1247-1253.

[38] Rainsford KD, Parke AL, Clifford-Rashotte M et al. Therapy and pharmacological properties of hydroxychloroquine and chloroquine in treatment of systemic lupus erythematosus, rheumatoid arthritis and related diseases. Inflammopharmacol. 2015; 23:231-269. https://doi.org/10.1007/s10787-015-0239-y.

[39] Kelleni M. Nitazoxanide/Azithromycin combination for COVID-19: A suggested new protocol for COVID-19 early management. 2020. 
[40] Hoffmann M, SchroederS, Kleine-Weber H, Müller MA, Drosten C, Pöhlmann S. Nafamostat mesylate blocks activation of SARS-CoV-2: New treatment option for COVID-19. Antimicrobial Agents and Chemotherapy. 2020.

[41] Dey SK, Saini M, Dhembla C, Bhatt S, Rajesh AS, Anand V, Kundu S. Suramin, Penciclovir and Anidulafungin bind nsp12, which governs the RNA-dependent-RNA polymerase activity of SARS-CoV-2, with higher interaction energy than Remdesivir, indicating potential in the treatment of Covid-19 infection. 2020.

[42] Dyall J, Coleman CM, Hart BJ, VenkataramanT, Holbrook MR, Kindrachuk J, JohansenLM. Repurposing of clinically developed drugs for treatment of Middle East respiratory syndrome coronavirus infection. Antimicrobial agents and chemotherapy. 2014; 58(8): 4885-4893.

[43] Ter Meulen J, Van Den Brink EN, Poon LL, Marissen WE, Leung CS, CoxF, Preiser W. Human monoclonal antibody combination against SARS coronavirus: synergy and coverage of escape mutants, PLoS Med. 2006; 3(7):e237.

[44] Falzarano D, De Wit E, Rasmussen AL, Feldmann F, Okumura A, Scott DP, Benecke AG. Treatment with interferon- $\alpha 2 b$ and ribavirin improves outcome in MERS-CoV-infected rhesus macaques. Nature medicine. 2013; 19(10): 1313-1317.

[45] Chan JF. W, Yao Y, Yeung ML, Deng W, Bao L, Jia L, Cai JP. Treatment with lopinavir/ritonavir or interferon- $\beta 1 \mathrm{~b}$ improves outcome of MERS-CoV infection in a nonhuman primate model of common marmoset. The Journal of infectious diseases. 2015; 212(12): 19041913.

[46] Hart BJ, Dyall J, Postnikova E, Zhou H, Kindrachuk J, Johnson RF, Olinger GG, Frieman MB, HolbrookMR, Jahrling PB, HensleyL. Interferon- $\beta$ and mycophenolic acid are potent inhibitors of Middle East respiratory syndrome coronavirus in cell-based assays. The Journal of general virology. 2014;95: 571-577. https://doi.org/10.1099/vir.0.061911-0.

[47] Shalhoub S, Farahat F, Al-Jiffri A, Simhairi R, Shamma O, Siddiqi N, Mushtaq A. IFN- $\alpha 2 a$ or IFN- $\beta 1 \mathrm{a}$ in combination with ribavirin to treat Middle East respiratory syndrome coronavirus pneumonia: a retrospective study. Journal of Antimicrobial Chemotherapy. 2015; 70( 7): 21292132.

[48] Beigel JH et al. Remdesivir for the treatment of COVID-19-preliminary report. N Engl J Med (Epub ahead of print 2020 May 22).2020. Available at: https://doi.org/10.1056/NEJMoa2007764.

[49] Harrison C. Coronavirus puts drug repurposing on the fast track. Nature biotechnology. 2020; 38 (4): 379-381. https ://doi.org/10.1038/, d4158 7-020-00003 -1.

[50] Gautret P, Lagier JC, Parola P et al. Hydroxychloroquine and azithromycin as a treatment of COVID-19: results of an open-label non-randomized clinical trial. Int J Antimicrob Agents. 2020; 56(1): 105949. doi:10.1016/j.ijantimicag.2020.105949.

[51] Doi K, Ikeda M, Hayase $\mathrm{N}$ et al. Nafamostat mesylate treatment in combination with favipiravir for patients critically ill with Covid-19: a case series. Crit Care. 2020; 24: 392. https://doi.org/10.1186/s13054-020-03078-z.

[52] Hung IFN, Lung KC, Tso EYK, LiuR, Chung TWH, Chu M, Shum HP. Triple combination of interferon beta-1b, lopinavir-ritonavir, and ribavirin in the treatment of patients admitted to hospital with COVID-19: an open-label,randomised, phase 2 trial. The Lancet. 2020;395(10238): 1695-1704.

[53] Thorlund K, Dron L, Park J, Hsu G, Forrest JI, Mills EJ. A real-time dashboard of clinical trials for COVID-19. The Lancet Digital Health. 2020: 2(6): e286-e287. 
[54] Furuta Y, Takahashi K, Fukuda Y, Kuno M, Kamiyama T, Kozaki K, Nomura N, Egawa H, Minami S, Watanabe Y, Narita $\mathrm{H}$, Shiraki K. In vitro and in vivo activities of anti-influenza virus compound T-705, Antimicrob. Agents Chemother. 2002; 46: 977-981.

[55] Shannon A, Selisko B, Le NTT, Huchting J, Touret F, Piorkowski G, Canard B. Favipiravir strikes the SARS-CoV-2 at its Achilles heel. the RNA polymerase. 2020. BioRxiv.

[56] Kaur RJ, Charan J, Dutta S, Sharma P, Bhardwaj P, Sharma P, Misra S. Favipiravir Use in COVID-19: Analysis of Suspected Adverse Drug Events Reported in the WHO Database. Infection and drug resistance. 2020; 13: 4427.

[57] Ben-Zvi I, Kivity S, Langevitz $\mathrm{P}$ et al. Hydroxychloroquine: From Malaria to Autoimmunity. Clinic Rev Allerg Immunol. 2012; 42:145-153. https://doi.org/10.1007/s12016010-8243-x.

[58] D'Acquarica I, AgranatI. Chiral switches of chloroquine and hydroxychloroquine: potential drugs to treat COVID-19. Drug Discovery Today 25.2020. https://doi.org/10.1016/j.drudis.2020.04.021.

[59] Hurt AC, Holien JK, Parker MW et al. Oseltamivir Resistance and the H274Y Neuraminidase Mutation in Seasonal. Pandemic and Highly Pathogenic Influenza Viruses. Drugs. 2009; 69: 2523-2531.https://doi.org/10.2165/11531450-000000000-00000.

[60] Wu F, Zhao S, Yu B, Chen Y-M, Wang W, Song ZG, Hu Y, Tao ZW, Tian JH, Pei YY, Yuan ML, Zhang YL, Dai FH,Liu Y, Wang QM, Zheng JJ, Xu L, Holmes EC, Zhang YZ. A new coronavirus associated with human respiratory disease in China. Nature. 2020; 579(7798): 265269. https://doi.org/10.1038/s41586-020-2008-3.

[61] Yin W, Mao C, Luan X, Shen DD, Shen Q, Su H, Chang S. Structural basis for inhibition of the RNA-dependent RNA polymerase from SARS-CoV-2 by Remdesivir, Science. 2020.

[62] Jiang F, Deng L, Zhang L, Cai Y, CheungCW, Xia Z. Review of the clinical characteristics of coronavirus disease 2019 (COVID-19). Journal of General Internal Medicine. 2020; 35(5): 15451549. https://doi.org/10.1007/s11606-020-05762-w.

[63] Choudhary MI, Shaikh M, tul-Wahab A, ur-Rahman A. In silico identification of potential inhibitors of key SARS-CoV-2 3CL hydrolase (Mpro) via molecular docking, MMGBSA predictive binding energy calculations, and molecular dynamics simulation. Plos one. 2020; 15(7):e0235030.

[64] Frecer V, Miertus S. Antiviral agents against COVID-19: structure-based design of specific peptidomimetic inhibitors of SARS-CoV-2 main protease. RSC Advances. 2020; 10(66): 4024440263.

[65] Di Micco S, Musella S, Scala MC, Sala M, Campiglia P, Bifulco G, Fasano A. In silico Analysis Revealed Potential Anti-SARS-CoV-2 Main Protease Activity by the Zonulin Inhibitor Larazotide Acetate. Frontiers in Chemistry. 2021; 8:1271.

[66] Gupta S, Singh AK, Kushwaha PP, Prajapati KS, Shuaib M, Senapati S, Kumar S. Identification of potential natural inhibitors of SARS-CoV2 main protease by molecular docking and simulation studies. Journal of Biomolecular Structure and Dynamics. 2020; 112.https://doi.org/10.1080/07391102.2020.1776157.

[67] SepayNayim et al. Anti-COVID-19 terpenoid from marine sources: A docking, admet and molecular dynamics study.Journal of molecular structure. 2021;1228: 129433.https://doi.org/10.1016/j.molstruc.2020.129433.

[68] Burley SK, Berman HM, Bhikadiya C, Bi C, Chen L, Di Costanzo L, Christie C, Dalenberg K, Duarte JM, Dutta S, Feng Z, GhoshS, Goodsell DS, Green RK, Guranovi_c V, Guzenko D, HudsonBP, Kalro T, Liang Y,Zardecki C. RCSB Protein Data Bank: Biological macromolecular 
structures enabling research and education in fundamental biology, biomedicine, biotechnology and energy. Nucleic Acids Research. 2019;47(D1): D464-D474. doi:10.1093/nar/gky1004.

[69] Dassault Syst'emes BIOVIA. Discovery Studio Modeling Environment. Release 2017, San Diego: Dassault Syst`emes.

[70] Morris GM, Huey R, Lindstrom W, SannerMF, Belew RK,GoodsellDS, Olson AJ. AutoDock4 and Auto Dock Tools4: Automated docking with selective receptor flexibility. Journal of Computational Chemistry. 2009; 30(16): 2785-2791. doi:10.1002/jcc.21256.

[71] Tools A. 1.5. 6 (ADT)/MGL Tools 1.5. 6.2012.

[72] Daina A, Michielin O, Zoete V. Swiss ADME: a free web tool to evaluate pharmacokinetics, drug-likeness and medicinal chemistry friendliness of small molecules. Sci. Rep. 2017;7: 42717, https://doi.org/10.1038/srep42717.

[73] Lipinski CA. Lead- and drug-like compounds: The rule-of-five revolution. Drug Discovery Today. Technologies. 2004; 1(4): 337-341. https://doi.org/10.1016/j.ddtec.2004.11.007.

[74] Apparsundaram S, Ferguson SM, George Jr AL, Blakely RD. Molecular cloning of a human, hemicholinium-3-sensitive choline transporter.Biochem. Biophys. Res. Commun.2000; 276: 862867.

[75] Veber DF, Johnson SR, Cheng HY, Smith BR, Ward KW, Kopple KD. Molecular properties that influence the oral bioavailability of drug candidates. J. Med. Chem.2002; 45 (12): 2615-2623.

[76] Becke A. A new inhomogeneity parameter in density-functional theory. Journal of Chemical Physics. 1997; 10(20) 8554-8560. https://doi.org/10.1063/1.475007.

[77] Frisch MJ. Gaussian 09, revision D.01. Gaussian Inc.2004.

[78] Dennington R, Keith T, Millam J. Gauss View, Version 4.1.2, Semichem, Inc., Shawnee Mission, KS.2007.

[79] Selvaraj C, Panwar U, Dinesh DC, Boura E, Singh P, Dubey VK, Singh SK. Microsecond MD Simulation and Multiple-Conformation Virtual Screening to Identify Potential Anti-COVID-19 Inhibitors Against SARS-CoV-2 Main Protease. Front. Chem. 2020;8: 595273. doi: 10.3389/fchem.

[80] Martorana A, Gentile C, Lauria A. In Silico Insights into the SARS CoV-2 Main Protease Suggest NADH Endogenous Defences in the Control of the Pandemic Coronavirus Infection. Viruses. 2020;12(8): 805.

[81] Trott O, Olson AJ. AutoDock Vina: improving the speed and accuracy of docking with a new scoring function, efficient optimization, and multithreading. J. Comput. Chem. 2010; 31(2): 455461, https://doi.org/10.1002/jcc.21334.

[82] Berendsen HJC, van der Spoel D, van Drunen R. GROMACS: A message passing parallel molecular dynamics implementation. Computer Physics Communications. 1995; 91: 43-56. https://doi.org/10.1016/0010-4655(95)00042-E.

[83] McDowell SE, Spackova Nada, Sponer J, Walter NG. Molecular Dynamics Simulations of RNA: An In Silico Single Molecule Approach. Biopolymers. 2007; 2(85): 169-184. doi:10.1002/bip.20620.

[84] Benson NC, Daggett V. A comparison of multiscale methods for the analysis of molecular dynamics simulations. The Journal of Physical Chemistry. B. 2012; 116(29): 8722-8731. https://doi.org/10.1021/jp302103t 22494262.

[85] Gunsteren WFV, Billeter SR, Eising AA, Hünenberger PH, Krüger P, Mark AE, Scott WRP, Tironi IG. Biomolecular simulation: The GROMOS96 manual and user guide. Hochschulverlag AG an der ETH Zürich, Zürich.1996. 
[86] Anuj K, Gaurav C, Sanjeev KS, Mansi S, Pankaj T, Arvind V, Madhu S. Identification of phytochemical inhibitors against main protease of COVID-19 using molecular modeling approaches. Journal of Biomolecular Structure and Dynamics.2020. https://doi.org/10.1080/07391102.2020.1772112.

[87] Rana M, Chowdhury P. Perturbation of hydrogen bonding in hydrated pyrrole-2-carboxaldehyde complexes, Journal of molecular modeling. 23(7) 216.

[88] Pooja, Rana M, Chowdhury P. Influence of size and shape on optical and electronic properties of CdTe quantum dots in aqueous environment. In AIP Conference Proceedings . 2019; 2136: 040006. AIP Publishing LLC

[89] Rashmi K, Rajendra K, Andrew L. g_mmpbsa-a GROMACS tool for high-throughput MMPBSA calculations. J. Chem. Inf. Model.2014; 54(7): 1951-1962. https://doi.org/10.1021/ci500020m.

[90] Kollman PA, Massova I, Reyes C, Kuhn B, Huo SH, Chong L et al. Calculating structures and free energies of complex molecules: combining molecular mechanics and continuum models. Acc. Chem. Res.2000; 33: 889-897. https://doi.org/ 10.1021/ar000033j.

[91] Stephen LM et al. DREIDING: a generic force field for molecular simulations. J. Phys. Chem.1990; 94(26): 8897-8909, https://doi.org/10.1021/j100389a010.

[92] Dharmendra KY et al. Molecular insights into the interaction of RONS and Thieno [3,2-c]pyran analogs with SIRT6/COX-2: a molecular dynamics study. Scientific Reports. .2018; 8: 4777. https://doi.org/10.1038/s41598-018-22972-9. 


\section{Supplementary Files}

This is a list of supplementary files associated with this preprint. Click to download.

- ResearchHighlights.docx

- Supportingdocument.docx

- graphicalabstract.pdf 